\begin{tabular}{|c|c|}
\hline Title & Heterogeneous beliefs and housing-market boom-bust cycles \\
\hline Author(s) & Tomura, Hajime \\
\hline Citation & $\begin{array}{l}\text { Journal of Economic Dynamics and Control, 37(4), 735-755 } \\
\text { https://doi.org/10.1016/.j.jedc.2012.11.002 }\end{array}$ \\
\hline Issue Date & $2013-04$ \\
\hline Doc URL & http:/hdl.handle.net/2115/52667 \\
\hline Type & article (author version) \\
\hline File Information & JEDC37-4_735-755.pdf \\
\hline
\end{tabular}

Instructions for use 


\title{
Heterogeneous Beliefs and Housing-Market Boom-Bust Cycles
}

\author{
Hajime Tomura* \\ Bank of Canada
}

November 08,2012

\begin{abstract}
This paper presents a business cycle model capturing the stylized features of housingmarket boom-bust cycles in developed countries. The model implies that over-optimism of mortgage borrowers generates housing-market boom-bust cycles, if mortgage borrowers are credit-constrained and savers do not share their optimism. This result holds without price stickiness. If price stickiness is introduced into the model, then the model replicates a low policy interest rate during a housing boom as an endogenous reaction to a low inflation rate, given a Taylor rule. Thus, monetary easing observed during housing booms are consistent with the presence of over-optimism causing boom-bust cycles.
\end{abstract}

Keywords: Asset price bubbles, Monetary policy, Financial liberalization, House prices, Credit constraints.

*Email: tomura.hajime@gmail.com. Address: Graduate School of Economics and Business Administration, Hokkaido University, Kita 9 Nishi 7, Kita-ku, Sapporo 060-0809, Japan. Tel/Fax: +81-11-706-2793. This work was done while I was affiliated with the Bank of Canada. The views expressed herein are those of the author and should not be interpreted as those of the Bank of Canada. 


\section{Introduction}

Strong booms in housing markets often end with significant drops in house prices. One of the explanations for these boom-bust cycles is over-optimism, while another explanation emphasizes the role of monetary easing. ${ }^{1}$ In this paper, I investigate the roles of these two factors in the formation of housing-market boom-bust cycles in a business cycle model. The model implies that over-optimistic expectations of mortgage borrowers about future technological progress generate a boom-bust cycle, if mortgage borrowers are credit-constrained and savers do not share their over-optimism. This result holds without price stickiness. In the presence of price stickiness, the model replicates a low policy interest rate during a housing boom as an endogenous reaction to a low inflation rate, given a Taylor rule. Thus, monetary easing observed during housing booms are consistent with the presence of over-optimism as the cause of housing-market boom-bust cycles.

The model is a version of news-shock model. In the model, households receive noisy public signals (i.e., news) about future technological progress. A favourable signal generates over-optimism ex-post, if technological progress does not occur as signaled. The model incorporates two types of households: one is mortgage borrowers, who finance housing investments through mortgage debt; and the other is savers, who lend to mortgage borrowers. Mortgage borrowers can borrow only up to the collateral value of housing, as in Iacoviello's (2005) model. The two types of households have time-invariant beliefs on the accuracy of public signals. Thus, households form heterogeneous expectations in response to a public signal, if their beliefs are different.

A public signal of future technological progress does not cause an expectation-driven housing boom, if both mortgage borrowers and savers become optimistic. In this case, a rise in the real interest rate due to savers' optimistic expectations dampens housing investments by mortgage borrowers. In contrast, an expectation-driven housing boom occurs if savers regard a public signal of future technological progress as a noise. In this case, the real interest rate does not rise because only mortgage borrowers become optimistic. As a result, a housing boom occurs as mortgage borrowers increase their housing investments on optimistic expectations about future house prices. A housing boom collapses when the optimistic expectations of mortgage borrowers turn out to be wrong ex-post.

In this cycle, output co-moves with the real house price because of borrowing constraints on mortgage borrowers. Optimistic borrowers increase labour supply during a housing boom, because borrowing constraints make it necessary for them to raise internal funds to finance their housing investments. As a result, aggregate labour supply, and hence output, rise during a housing boom. Furthermore, if price stickiness is introduced into the model, then this effect leads to endogenous monetary easing during a housing boom. In the presence of price stickiness, an increase in aggregate labour supply lowers the inflation rate through a decline in real wages during a housing boom. In response, the central bank lowers the policy rate, given a Taylor rule.

These results replicate the stylized features of housing-market boom-bust cycles in devel-

\footnotetext{
${ }^{1}$ See Taylor (2009) for example.
} 
oped countries. As shown in Section 2, real aggregate quantity variables and the real house price have tended to co-move during boom-bust cycles. In contrast, the inflation rate and the short-term nominal interest rate have tended to be low during housing booms. Moreover, in comparison between young and old households, the hours worked of young households have tended to be the main driver of an increase in aggregate labour supply during housing booms. Given the fact that mortgage borrowers tend to be young in reality, this observation is consistent with the role of mortgage borrowers' labour supply in the model.

Also, the focus on heterogeneous expectations is supported by data. The real house price growth rate in U.S. has been closely correlated with the excess of young households' confidence in future aggregate economic activity over old households' confidence in survey data. This observation is consistent with the effects of heterogeneous expectations between mortgage borrowers and savers in the model.

\subsection{Related literature}

This paper adds to the literature on news-shock models, such as Beaudry and Portier (2004) and (2007), Jaimovich and Rebelo (2009), Christiano et al. (2010), and Schmitt-Grohé and Uribe (2008). Considering time-invariant, heterogeneous household beliefs on the accuracy of public signals contrasts with the standard assumption in this literature that all households form homogeneous expectations from public signals.

In this regard, this paper is related to a vast literature on heterogeneous expectations with boundedly rational agents (see Hommes 2006 for an extensive survey). In this literature, agents form heterogeneous expectations using different forecasting rules. It is found that heterogeneous expectations sustain in the long run even if each agent updates the agent's forecasting rule on a performance basis (see Branch and Evans 2006, for example.) Recently, Anufriev et al. (forthcoming), Branch and McGough (2009) and De Grauwe (2011) analyze how the presence of heterogeneous expectations affect the properties of New-Keynesian models. ${ }^{2}$ This paper adds to these papers by introducing heterogeneous expectations into a New-Keynesian model with a housing market and borrowing constraints. The result that heterogeneous expectations lead to a housing-market boom-bust cycle in a New-Keynesian model contributes to the literature on the effects of monetary policy during asset bubbles, such as Bernanke and Gertler (1999, 2001), Cecchetti et al. (2000), Gilchrist and Leahy (2002), and Dupor (2005).

Regarding the interaction between heterogeneous expectations and borrowing constraints, there exists a behavioural finance literature that analyzes the effects of heterogeneous investor beliefs and short-sales constraints on asset prices. See Hong and Stein (2007) for a review of this literature. Also, Geanakoplos (2009) and Fostel and Geanakoplos (2008) provide

\footnotetext{
${ }^{2}$ Related to these theoretical papers, Assenza et al. (2011) conduct laboratory experiments in an artificial New-Keynesian economy. They examine how their human subjects select different forecasting rules and analyze how the effect of monetary policy is affected. Also, Cornea et al. (2012) estimate on U.S. inflation data a New-Keynesian Phillips curve with heterogeneous expectations due to endogenous selection of forecasting rules.
} 
a finite-horizon model to analyze the role of heterogeneous investor beliefs and borrowing constraints in the formation of asset-market boom-bust cycles. They consider endogenous borrowing constraints based on Value-at-Risk, which generates pro-cyclical leverage. Fostel and Geanakoplos (2011) show that default can occur with this type of constraint. This paper is different from their work in introducing heterogeneous expectations into a standard DSGE (i.e., a business cycle) model based on Iacoviello (2005), which nests a New-Keynesian model. This feature of this paper leads to the finding that heterogeneous expectations are crucial for an expectation-driven housing boom because they prevent a rise in the real interest rate.

Other work on heterogeneous expectations includes Burnside et al. (2011). They model social dynamics among households with heterogeneous expectations during housing-market boom-bust cycles. This paper differs from their analysis since Burnside et al.'s model abstracts from financial frictions. Favara and Song (2010) analyze the role of heterogeneous household expectations in generating geographical heterogeneity in housing markets using a model with an exogenous real interest rate. In contrast, this paper analyzes the business cycle features of housing-market boom-bust cycles in a model with an endogenous real interest rate. Also, Piazzesi and Schneider (2008) quantify the effects of heterogeneous household expectations in an overlapping generations model by using household survey data directly as the values of household expectations.

Finally, the model is related to the recent literature that analyzes the role of the demographic difference in labour supply elasticity in the business cycle. In this paper, boom-bust cycles occur with homogeneous elasticity of labour supply, if prices are flexible. To generate boom-bust cycles in the presence of price stickiness, however, it is necessary to assume that mortgage borrowers have a higher elasticity of labour supply than savers, so that mortgage borrowers dominate the movement of aggregate labour supply. This assumption is consistent with the fact that the labour supply of young households tends to be more volatile than that of old households, as observed by Jaimovich and Siu (2009). This paper confirms the importance of the demographic difference in labour supply elasticity in the business cycle, as demonstrated by Jaimovich and Siu and also Campbell and Hercowitz (2004). ${ }^{3}$

\section{Empirical motivation}

\subsection{Stylized features of housing-market boom-bust cycles in de- veloped countries}

Figure 1 summarizes the average dynamics of macroeconomic variables during housingmarket boom-bust cycles in developed countries between the 1970s and the 1990s. Since the levels of the variables are not necessarily stationary across countries or time periods, the variables in each boom-bust episode (except real house price growth rates) are normalized to have zero mean over the 40-quarter or 10-year time window around the peak quarter or year of the boom. Each panel in the figure shows the median of the normalized variables in

\footnotetext{
${ }^{3}$ Campbell and Hercowitz (2004) assume no labour supply of savers in their business cycle model.
} 
each period of the time window. ${ }^{4}$ While the panel for real house price growth rates exhibits median growth rates to show the average magnitude of past booms and busts, the panel does not change much even if the data are as normalized as the other variables.

The figure shows that the growth rates of aggregate output and hours worked have tended to be high during housing booms and low after the ends of booms. These pro-cyclical fluctuations in aggregate hours worked have tended to be driven by the labour supply of young workers, since the figure shows that the employment of young workers (under 44 years old) has tended to grow strongly during booms and weakly after booms, whereas the employment of old workers (over 44 years old) has tended not to show such a pattern. ${ }^{5}$ On the price side, CPI inflation rates and short-term nominal interest rates, which are closely correlated with policy interest rates, have tended to be low during booms and rising around the ends of booms. ${ }^{6}$ Similarly to these nominal variables, short-term real interest rates and the growth rates of real wages measured by hourly earnings in manufacturing have tended to decline temporarily during booms before rising around the ends of booms. ${ }^{7}$ After the ends of booms, real wage growth rates have tended to decline significantly. See Table 1 for the peak quarters of the booms identified by Ahearne et al. (2005) and also Appendix A for data details. ${ }^{8}$

\subsection{Heterogeneous household expectations and real house price growth rates in U.S. data}

In this paper, I present a business cycle model with heterogeneous household expectations which can generate the stylized features of housing-market boom-bust cycles summarized above, except the significant declines in real wage growth rates after the ends of booms. Figure 2 shows suggestive evidence from U.S. data to motivate this consideration. The figure compares the nationwide real house price growth rate with the difference in the Index of Consumer Expectations (ICE) between young (under 44 years old) and old (over 45

\footnotetext{
${ }^{4}$ To construct each panel in the figure, normalize each variable for each boom-bust episode by subtracting from the variable the average of the variable over the time window around the peak of the boom. Then, pool normalized values across boom-bust cycles and derive the median of the pooled values for each period of the time window. In each panel, the time window shown is centered around the peak periods of the booms.

${ }^{5}$ Age-specific actual hours worked data are not available across countries in the OECD database.

${ }^{6}$ This result is consistent with the findings by Bordo and Jeanne (2002) and Ahearne et al. (2005) using similar methodologies, as well as the event study by Borio and Lowe (2002). While Detken and Smets (2004) also find counter-cyclical fluctuations in policy interest rates during past boom-bust cycles in asset markets, including both equity and real estates, they emphasize rising inflation during booms.

${ }^{7}$ Here, I use hourly earnings data as the wage measure because of concern on measurement error in the data on compensations per hour, which are much more volatile than earnings data, as discussed by Galí (2011). Also, I use hourly earnings in manufacturing because the data on hourly earnings in private sectors before the mid-1990s do not exist for most of the countries in the OECD database.

${ }^{8}$ Similar results to Figure 1 hold in the pre-1985 and the post-1985 subsample periods, except for employment growth rates for young and old workers. While there was no significant difference in the employment growth rate between young and old workers in the pre-1985 subsample period, a similar difference to Figure 1 was observed in the post-1985 subsample period.
} 
years old) households. The ICE is provided by the Reuters/University of Michigan Surveys of Consumers and consists of the responses to three survey questions about the expected future financial condition for the respondent herself and the expected future financial and employment condition in the economy. The figure indicates that the real house price growth rate has tended to be high when young households are more optimistic about future economic conditions than old households. The correlation coefficient between the two variables in the figure is 0.29 over the entire sample period.

To confirm the correlation between heterogeneous household expectations and real house price growth rates more formally, Table 2 shows the OLS estimates of the regression of the real house price growth rate on the difference in the ICE between young and old households and the other regressors listed in the table. Confirming the implication of Figure 2, the estimated coefficient of the contemporaneous difference in the ICE between young and old households is significantly positive at $1 \%$ significance level.

Since the model shown below will focus on household expectations about aggregate economic conditions, Figure 2 also shows each of the two questions about future aggregate economic conditions in the ICE, that is, the expected financial condition in the economy during the next 12 months (labeled "BUS12") and the expected employment condition in the economy during the next 5 years (labeled "BUS5"). The difference between young and old households in each variable is highly correlated with the real house price growth rate similarly to the ICE. ${ }^{9}$

In the following, I present a business cycle model in which over-optimistic expectations of mortgage borrowers, who tend to be young in practice, generate housing-market boom-bust cycles along with aggregate features summarized by Figure 1.

\section{The model}

\subsection{Firms}

There is a continuum of households who consume final goods, which are produced by a CES function of intermediate inputs:

$$
y_{t}=\left[\int_{0}^{1}\left(y_{j, t}\right)^{\frac{\theta-1}{\theta}} d j\right]^{\frac{\theta}{\theta-1}},
$$

where $y_{t}$ is the amount of final goods produced, $y_{j, t}$ is the amount of intermediate inputs of variety $j$, and $\theta(\geq 0)$ is the elasticity of substitution. Each variety of intermediate inputs is produced by technology represented by a standard Cobb-Douglas function:

$$
y_{j, t}=\left(k_{j, t}\right)^{\alpha}\left(A_{t} l_{j, t}\right)^{1-\alpha},
$$

\footnotetext{
${ }^{9}$ In the figure, the correlation coefficient with the real house price growth rate is 0.23 for the difference in BUS12 and 0.26 for the difference in BUS5. Also, the results shown in Table 2 do not significantly change even if the ICE is replaced by BUS12. If the ICE is replaced by BUS5, the coefficient of the contemporaneous difference in the BUS5 remains positive, even though it becomes insignificant at $10 \%$ significance level.
} 
where $k_{j, t}$ is rented capital stock, $A_{t}$ is labour augmenting technology, $l_{j, t}$ is employed hours worked, and $\alpha(\in(0,1))$ is the capital share in the cost of production.

Final-good producers take prices as given, earning zero profit. Cost minimization by finalgood producers implies that the demand function for each variety of intermediate inputs is:

$$
y_{j, t}=\left(\frac{P_{j, t}}{P_{t}}\right)^{-\theta} y_{t}
$$

where $P_{j, t}$ is the nominal price for the variety $j$ of intermediate inputs and $P_{t}$ is the aggregate price index defined by:

$$
P_{t}=\left[\int_{0}^{1}\left(P_{j, t}\right)^{1-\theta} d j\right]^{\frac{1}{1-\theta}} .
$$

The index $P_{t}$ is the nominal unit production cost of final goods when final-good producers minimize the production cost. Since the final-good market is competitive, $P_{t}$ becomes the nominal price of final goods.

Each variety of intermediate inputs is produced by a monopolistic producer. Each monopolistic producer can only infrequently adjust the price of one's product with probability $1-\chi(\chi \in[0,1))$ every period, maximizing the present discounted value of profits while the price remains fixed:

$$
\max _{P_{j, t}} E_{t}^{\prime}\left[\sum_{s=t}^{\infty} \chi^{s-t} \Lambda_{t, s}\left(P_{j, t}-P_{s} f_{s}\right) y_{j, s}\right],
$$

subject to the production function (2) and the demand function (3), taking the probability distribution of $\left\{\Lambda_{t, s}, f_{s}, y_{s}, P_{s}\right\}_{s=t}^{\infty}$ as given. The operator $E_{t}^{\prime}$ in the maximization problem is the subjective conditional expectation operator, and the variable $\Lambda_{t, s}$ is the stochastic discount factor between periods $t$ and $s$ for intermediate-input producers. The variable $f_{s}$ is the real marginal cost of production for intermediate-input producers. Cost minimization by intermediate-input producers in competitive factor markets implies that:

$$
f_{t}=\left(\frac{r_{K, t}}{\alpha}\right)^{\alpha}\left[\frac{w_{t}}{(1-\alpha) A_{t}}\right]^{1-\alpha},
$$

where $r_{K, t}$ and $w_{t}$ are the rental price of capital and the real wage rate, respectively. Factor demand, $\left\{k_{j, t}, l_{j, t} \mid j \in[0,1]\right\}$, is determined by cost minimization by intermediate-input producers:

$$
k_{j, t}=\frac{\alpha f_{t} y_{j, t}}{r_{K, t}} \quad \text { and } \quad l_{j, t}=\frac{(1-\alpha) f_{t} y_{j, t}}{w_{t}} \text { for } j \in[0,1]
$$




\subsection{Households}

There are two types of households. One type has a higher time discount factor than the other. Label the former type "savers" and the latter type "mortgage borrowers". The saver fraction of the population is $\mu(\in(0,1])$, and the mortgage-borrower fraction is $1-\mu$.

I consider a "cash-less" economy where the money balance is negligible as part of financial assets. Each saver maximizes the utility function:

$$
E_{t}^{\prime}\left\{\sum_{s=t}^{\infty}\left(\beta^{\prime}\right)^{s-t}\left[\ln \left(c_{s}^{\prime}\right)+\gamma \ln \left(h_{s}^{\prime}\right)-\frac{\left(l_{s}^{\prime}\right)^{1+\xi}}{1+\xi}\right]\right\},
$$

where $E_{t}^{\prime}$ is the subjective expectation operator conditional on the information set at $t$ for savers, $\beta^{\prime}(\in(0,1))$ is the time discount factor, $c_{t}^{\prime}$ is consumption, $h_{t}^{\prime}$ is housing stock, $l_{t}^{\prime}$ is hours worked, and $\gamma>0$ and $\xi>0$. The prime symbol $\left({ }^{\prime}\right)$ denotes the variables and the parameters for savers.

Savers are subject to the following flow of funds constraint and the law of motion for capital stock:

$$
\begin{gathered}
c_{t}^{\prime}+\frac{\eta_{K}}{2}\left(\frac{i_{t}^{\prime}}{s_{t-1}^{\prime}}\right)^{2} s_{t-1}^{\prime}+q_{t}\left(h_{t}^{\prime}-h_{t-1}^{\prime}\right)+b_{t}^{\prime}=w_{t} l_{t}^{\prime}+r_{K, t} s_{t-1}^{\prime}+\frac{R_{t-1}}{\pi_{t}} b_{t-1}^{\prime}+\Gamma_{t}, \\
s_{t}^{\prime}=i_{t}^{\prime}+(1-\delta) s_{t-1}^{\prime},
\end{gathered}
$$

where $i_{t}^{\prime}$ is the increment of capital stock, $s_{t}^{\prime}$ is the amount of capital stock at the end of period $t, \delta$ is the depreciation rate of capital stock, $q_{t}$ is the real price of housing stock, $b_{t}^{\prime}$ is the real balance of mortgage bonds, $R_{t}$ is the gross nominal interest rate, and $\pi_{t}$ is the gross rate of inflation, i.e., $P_{t} / P_{t-1} \cdot{ }^{10}$ The second term on the left-hand side of Eq. (9) is the investment cost function, where $\eta_{K}>0$. In the equilibrium analysis below, the convex investment cost will lead to co-movement between consumption and investment.

Savers receive the profits of intermediate-input producers as their shareholders. The real value of the transferred profits per saver, $\Gamma_{t}$, which appears on the right-hand side of Eq. (9), is determined by:

$$
\Gamma_{t}=\frac{1}{\mu} \int_{0}^{1}\left(\frac{P_{j, t}}{P_{t}}-f_{t}\right) y_{j, t} d j .
$$

I assume that intermediate-input producers and savers share the same subjective expectation operator, $E_{t}^{\prime}$. Also, they share a common stochastic discount factor, i.e., $\Lambda_{t, s}=\left(\beta^{\prime}\right)^{s-t} c_{t}^{\prime} / c_{s}^{\prime}$. These assumptions ensure that intermediate-input producers behave as if they maximize the utility function of savers.

Each mortgage borrower maximizes the utility function:

$$
E_{t}^{\prime \prime}\left\{\sum_{s=t}^{\infty}\left(\beta^{\prime \prime}\right)^{s-t}\left[\ln \left(c_{s}^{\prime \prime}\right)+\gamma \ln \left(h_{s}^{\prime \prime}\right)-\frac{\left(l_{s}^{\prime \prime}\right)^{1+\xi}}{1+\xi}\right]\right\},
$$

\footnotetext{
${ }^{10}$ While Eq. (9) implies that bonds are non-indexed, the results of the model do not change substantially even if I consider indexed bonds.
} 
where $\beta^{\prime \prime}\left(\in\left(0, \beta^{\prime}\right)\right)$, subject to the following flow of funds and borrowing constraints:

$$
\begin{gathered}
c_{t}^{\prime \prime}+q_{t}\left(h_{t}^{\prime \prime}-h_{t-1}^{\prime \prime}\right)+b_{t}^{\prime \prime}=w_{t} l_{t}^{\prime \prime}+\frac{R_{t-1}}{\pi_{t}} b_{t-1}^{\prime \prime}, \\
b_{t}^{\prime \prime} \geq-m E_{t}^{\prime}\left[\frac{\pi_{t+1} q_{t+1} h_{t}^{\prime \prime}}{R_{t}}\right] .
\end{gathered}
$$

The double-prime symbol $\left({ }^{\prime \prime}\right)$ denotes the variables for mortgage borrowers. The assumption that $\beta^{\prime \prime}$ is smaller than $\beta^{\prime}$ implies that mortgage borrowers value current consumption more than savers. This difference induces mortgage borrowers to be borrowers and savers to be lenders in the neighbourhood of the deterministic steady state. ${ }^{11}$

The flow of funds constraint (13) implies that mortgage borrowers do not hold capital. This assumption is set without loss of generality, because, given $\beta^{\prime \prime}<\beta^{\prime}$, mortgage borrowers do not buy capital from savers in the neighbourhood of the deterministic steady state, even if they can. ${ }^{12}$ The borrowing constraint (14) implies that mortgage borrowers can borrow only up to the collateral value of their houses, which is determined by the expected liquidation value of houses for lenders. Thus, the collateral value is evaluated by the saver expectations represented by $E_{t}^{\prime}$. The parameter $m$ controls the loan-to-value ratio at the steady state. ${ }^{13}$

\subsection{Real and nominal interest rates}

If goods prices are flexible (i.e., $\chi=0$ ), then the maximization problem for the intermediateinput producers described above implies $f_{t}=1-\theta^{-1}$ (i.e., a constant markup) and the dichotomy between real and nominal variables holds. In this case, I focus only on real variables, so I replace $R_{t} / \pi_{t+1}$ by the gross real interest rate, $r r_{t}$, for all $t$. If $\chi>0$, i.e., goods prices are sticky, then I assume that the central bank sets the nominal interest rate, $R_{t}$, following a standard Taylor rule:

$$
\widehat{R}_{t}=\left(1-\phi_{R}\right)\left(\phi_{\pi} \widehat{\pi}_{t}+\phi_{Y} \widehat{y}_{t}\right)+\phi_{R} \widehat{R}_{t-1}, \quad \text { if } \chi \in(0,1)
$$

where the hat symbol denotes log deviations of the variables from the deterministic steady state. ${ }^{14}$

\footnotetext{
${ }^{11}$ See Iacoviello (2005) for more details.

${ }^{12}$ See Appendix B for the proof.

${ }^{13}$ This type of constraint is introduced by Kiyotaki and Moore (1997). See Hart and Moore (1994) for the bargaining environment behind the borrowing constraints. In short, lenders can only foreclose on collateral if borrowers walk away from debt contracts. Borrowers renegotiate debt contracts if the value of future debt service exceeds the value of collateral. Lenders expect this and lend only up to the value of collateral. Also, Krishnamurthy (2010) reviews various types of borrowing constraints in the literature and shows that these constraints can be reduced to a similar form to the borrowing constraint (14). In addition, Geanakoplos (2009) and Brunnermeier and Pedersen (2009) propose alternative borrowing constraints that endogenize the parameter $m$. Integration of these constraints into a DSGE model, however, is yet to be done in the literature. This agenda is left for future research.

${ }^{14}$ Here, the monetary policy rule does not include the expected value of a future inflation rate or future output. This assumption obviates the need to specify the central bank's subjective expectation formation process, which would complicate the model.
} 


\subsection{Shock process, public signals, and heterogeneous beliefs}

I assume that labour augmenting technology, $A_{t}$, is driven by an $\operatorname{AR}(1)$ process: $\ln \left(A_{t}\right)=$ $\rho_{A} \ln \left(A_{t-1}\right)+\epsilon_{A, t}$, where $\epsilon_{A, t}$ is an i.i.d. shock distributed by $N\left(0, \sigma_{A}^{2}\right)$. Households receive public signals of $\epsilon_{A, t+\tau}$ in period $t$, where $\tau$ is a positive integer. Signals are generated by the following process: $z_{A, t}=\epsilon_{A, t+\tau}+\omega_{A, t}$, where $\omega_{A, t}$ is an i.i.d. noise distributed by $N\left(0, \nu_{A}^{2}\right)$.

I assume that households disagree on the accuracy of public signals, which is represented by $\nu_{A}$. I denote the beliefs of savers and mortgage borrowers by $\nu_{A}^{\prime}$ and $\nu_{A}^{\prime \prime}$, respectively. Their beliefs are fixed regardless of ex-post realizations of $\epsilon_{A, t}$. The stochastic processes for $A_{t}$ and $z_{t}$ defined above imply:

$$
\begin{aligned}
E^{\prime}\left[\epsilon_{A, t+\tau} \mid z_{A, t}\right] & =\frac{\sigma_{A}^{2} z_{A, t}}{\sigma_{A}^{2}+\left(\nu_{A}^{\prime}\right)^{2}}, \\
E^{\prime \prime}\left[\epsilon_{A, t+\tau} \mid z_{A, t}\right] & =\frac{\sigma_{A}^{2} z_{A, t}}{\sigma_{A}^{2}+\left(\nu_{A}^{\prime \prime}\right)^{2}} .
\end{aligned}
$$

Thus, public signals generate heterogeneous expectations if $\nu_{A}^{\prime} \neq \nu_{A}^{\prime \prime}{ }^{15}$

Even though rational households would update their beliefs on the accuracy of public signals, note that public signals in the model are a proxy for news about future technological progress in reality. Since every discovery of new technology is different, it is difficult to guess the accuracy of news about an expected discovery from past experience. The time-invariant household beliefs are a short-cut to reflect this difficulty. While it remains a question why household beliefs become heterogeneous in reality, this paper utilizes the type-specific household beliefs to generate heterogeneous household expectations between mortgage borrowers and savers, as suggested by the evidence described in Section 2.2.

\subsection{Equilibrium conditions}

Market prices are determined to satisfy market clearing conditions for hours worked, capital stock, housing stock, and mortgage bonds:

$$
\begin{gathered}
\int_{0}^{1} l_{j, t} d j=\mu l_{t}^{\prime}+(1-\mu) l_{t}^{\prime \prime}, \\
\mu s_{t-1}^{\prime}=\int_{0}^{1} k_{j, t} d j \\
\mu h_{t}^{\prime}+(1-\mu) h_{t}^{\prime \prime}=1 \\
\mu b_{t}^{\prime}+(1-\mu) b_{t}^{\prime \prime}=0
\end{gathered}
$$

where the supply of housing stock is fixed to 1 in Eq. (20). Thus, fluctuations in the real house price are demand-driven in the model. Eq. (19) implies that investments in capital by savers materialize one period later.

\footnotetext{
${ }^{15}$ Bolton et al. (2006) generate heterogeneous expectations in the same form as Eqs. (16) and (17).
} 
An equilibrium in the model is: the solutions to the maximization problems for intermediateinput producers, savers, and mortgage borrowers, given rational expectations of aggregate variables $\left(\left\{w_{s}, r_{K, s}, q_{s}, f_{s}, y_{s}, \Gamma_{s}\right\}_{s=t}^{\infty}\right.$, and $\left\{r r_{s}\right\}_{s=t}^{\infty}$ or $\left.\left\{\pi_{s}, R_{s}\right\}_{s=t}^{\infty}\right)$ conditional on each realization of technological shocks and public signals and also given the subjective likelihood of future technological shocks; and aggregate variables in each period determined by Eqs. (1), (2), (6)-(7), (11), (15) and (18)-(21).

The equilibrium in the model is similar to the standard competitive equilibrium, since agents hold rational expectations of equilibrium dynamics for each possible realization of shocks and public signals. The only difference from the standard competitive equilibrium is that households disagree on the likelihood of future shocks, given public signals.

\subsection{The numerical solution method}

I solve equilibrium dynamics numerically by the standard perturbation method, finding the exact state-space solution form for the system of equilibrium conditions log-linearized around the deterministic steady state. I use the undetermined coefficient method to find the statespace form:

$$
\left[\begin{array}{c}
\hat{x}_{t} \\
\hat{k k_{t+1}}
\end{array}\right]=\left[\begin{array}{lll}
C & D & F
\end{array}\right]\left[\begin{array}{c}
\hat{k k_{t}} \\
\epsilon_{A, t} \\
\zeta_{t}
\end{array}\right],
$$

where $\zeta_{t}=\left[z_{A, t}, \ldots, z_{A, t-\tau+1}\right]^{T}$, which is the vector of public signals of future technological shocks; $k k_{t+1}=\left[A_{t}, k_{t}^{\prime}, b_{t}^{\prime}, h_{t}^{\prime}, b_{t}^{\prime \prime}, h_{t}^{\prime \prime}\right]^{T}$, which is the vector of endogenous state variables determined in period $t$; and $x_{t}=\left[c_{t}^{\prime}, l_{t}^{\prime}, i_{t}^{\prime}, c_{t}^{\prime \prime}, l_{t}^{\prime \prime}, r r_{t}, q_{t}, r_{K, t}, w_{t}, f_{t}, y_{t}\right]^{T}$, which is the vector of jump variables. ${ }^{16}$ The hat symbol denotes the log deviations of the vectors from the deterministic steady state.

Given the assumption that the subjective expectations of future technological shocks depend only on exogenous public signals, $\zeta_{t}$, I can show that the values of $C$ and $D$ are identical to those in the case without public signals. ${ }^{17}$ This result implies that the firstorder effect of heterogeneous household expectations on model dynamics is captured by the additional disturbance term, $F \zeta_{t}$, which is transmitted intertemporally through changes in $\hat{k}_{t+1}$. The value of $F$ is determined so that $\zeta_{t}$ changes household behaviour in the current period directly through each household's subjective expectation of the economy in the next period and then indirectly through a feedback loop between household behaviour and market prices that continues until the markets clear. The values of $C, D$ and $F$ are determined uniquely for the parameter values considered in this paper. See Appendix $C$ for more details on the numerical solution method.

\footnotetext{
${ }^{16}$ These definitions of the vectors are for the flexible price case. In the sticky price case, include $R_{t}$ and $\pi_{t}$ in $k k_{t+1}$ and $x_{t}$, respectively, and remove $r r_{t}$ from $x_{t}$.

${ }^{17}$ Thus, these matrices can be obtained by the standard numerical solution method for rational expectations models described by Klein (2000).
} 


\section{Housing-market boom-bust cycles with flexible prices}

In the following, I describe the equilibrium dynamics of the model in response to a period-0 public signal $\left(z_{A, 0}\right)$ about a period-4 positive shock to technology $\left(\epsilon_{A, 4}\right)$. I start from the case with flexible prices (i.e., $\chi=0$ ) as the benchmark. I use standard parameter values in the literature. The unit of time in the model is a quarter. The capital share of aggregate factor income, $\alpha$, is 0.33 . The quarterly depreciation rate of capital, $\delta$, is 0.025 . The elasticity of substitution between varieties of inputs, $\theta$, is 11 , which implies a $10 \%$ steady-state markup. The autoregressive coefficient for realized productivity shocks, $\rho_{A}$, is 0.9 . The steady-state loan-to-value ratio for residential mortgages, $m$, is set to 0.8 , as assumed by Fisher and Gervais (2011) for the baseline case of their model. The lead of public signals, $\tau$, is assumed to be 4 periods, following Beaudry and Portier (2004). The fraction of credit-constrained mortgage borrowers, $1-\mu$, is 0.25 , which is the credit-constrained fraction of U.S. households estimated by Hajivassiliou and Ioannides (2007) using PSID data. ${ }^{18}$ The following parameter values are set as in Iacoviello (2005): the time discount factors of savers, $\beta^{\prime}$, and mortgage borrowers, $\beta^{\prime \prime}$, are 0.99 and 0.95 , respectively; the coefficient of the investment function, $\eta_{K}$, is $2 / \delta$; the weight on housing preference, $\gamma$, is 0.1 ; and the inverse of the Frisch elasticity of labour supply, $\xi$, is $0.01 .^{19}$ Table 3 summarizes the benchmark parameter values.

\subsection{Expectation-driven boom-bust cycles with borrowing constraints and heterogeneous household beliefs}

With borrowing constraints and heterogeneous beliefs, an ex-post wrong positive public signal about future technological progress causes expectation-driven boom-bust cycles in the model. This is shown by the solid lines in Figure 3, which are the impulse responses to an ex-post wrong public signal of future technological progress $\left(z_{A, 0}=1\right.$ and $\left.\epsilon_{A, 4}=0\right)$ when mortgage borrowers consider the signal accurate, but savers regard the signal as a noise (i.e., $\nu_{A}^{\prime}=\infty$ and $\left.\nu_{A}^{\prime \prime}=0\right) \cdot{ }^{20}$

In the figure, a housing boom occurs in response to a public signal of future technological progress, since mortgage borrowers increase housing investments on expectations of high future house prices. Also, borrowers work more to raise internal funds for financing their housing investments because of borrowing constraints, which results in an increase in aggregate labour supply. At the same time, as savers do not share the optimistic expectations of mortgage borrowers, they instead expect the boom to be temporary and increase savings

\footnotetext{
${ }^{18}$ This estimate for the credit-constrained fraction of households is similar to other estimates using micro data in the literature. For example, Grant (2007) estimates the fraction to be $31 \%$ using CEX data. Also, see Jappelli (1990) for a review of the estimates in earlier literature and his own estimate, which are around $20 \%$.

${ }^{19}$ Iacoviello specifies these parameter values before the estimation of his model.

${ }^{20}$ Complete agreement among savers is not necessary for the existence of an expectation-driven boom-bust cycle. For example, a boom-bust cycle occurs even if half of savers consider public signals accurate.
} 
for a future recession. An increase in savings finances housing investments by optimistic mortgage borrowers through mortgage debt and also expands savers' investments into capital. Increases in aggregate labour supply and investment in capital raise aggregate output. Subsequently, a housing bust occurs when the optimistic expectations of mortgage borrowers are not realized in period 4 . As the mechanism at work during the boom is reversed, savings and labour supply decline. Hence aggregate investment and output drop. ${ }^{21}$

Note that, with standard preferences assumed in this paper, changes in expectations cannot generate positive co-movement among aggregate consumption, investment, and labour supply in the standard neo-classical business cycle model, as shown by Beaudry and Portier (2004, 2007) and Jaimovich and Rebelo (2009). ${ }^{22}$ Thus, some kind of mechanism is necessary to move these aggregate variables together. In this paper, heterogeneous agents with borrowing constraints are fundamental for this: even though consumption and labour supply move in opposite directions at each household level as shown in Figure 3, it turns out that mortgage borrowers, who buy houses and consume less during booms, decide to work a lot because of borrowing constraints. In contrast, savers, who consume more because they sell their houses, do not reduce labour supply as much as an increase in credit-constrained mortgage borrowers' labour supply. Hence, aggregate consumption and labour supply comove. ${ }^{23}$ Also, expecting a future recession, savers increase investments in capital to save part of the revenue from their home sales, which makes aggregate investment move together with aggregate consumption.

This result replicates the co-movement among aggregate quantity variables observed during past housing-market boom-bust cycles, as shown in Figure $1 .{ }^{24}$ Especially, the heterogeneous labour supply of mortgage borrowers and savers is largely consistent with the fact that the labour supply of young households, who are a proxy for mortgage borrowers, has tended to be the driver of pro-cyclical fluctuations in aggregate labour supply during past boom-bust cycles. Also, in the model, pro-cyclical fluctuations in savings and aggregate labour supply lower the real interest rate and the real wage during a housing boom, and then raise them around the end of the boom. Such dynamics of the real interest rate and

\footnotetext{
${ }^{21}$ The boom-bust cycle described here does not depend on the cyclicality of mortgage borrowers' leverage measured by $q_{t} h_{t}^{\prime \prime} /\left(q_{t} h_{t}^{\prime \prime}+b_{t}^{\prime \prime}\right)$ (where $b_{t}^{\prime \prime}$ is negative). With Eq. (14), the leverage is counter-cyclical over the boom-bust cycle. Even though pro-cyclical leverage can be generated if $q_{t+1}$ in Eq. (14) is replaced by $q_{t}$, the model dynamics hardly change. This result holds because the key for the existence of an expectation-driven boom-bust cycle is that heterogeneous expectations dampen a rise in the real interest rate during a boom.

${ }^{22}$ This is also true in this paper if all households are patient (i.e., $\mu=1$.)

${ }^{23}$ As labour elasticity is set lower, mortgage borrowers finance their housing investments more by cutting consumption and less by increasing labour supply. If labour elasticity is set very low, then this effect makes aggregate consumption counter-cyclical over the boom-bust cycle, even though aggregate investment and labour supply remain pro-cyclical. The co-movement among aggregate consumption, investment, and labour supply, however, is robust to the range of the Frisch elasticity of aggregate hours worked $(1 / \xi)$ in the macroeconomic literature (from 2.84 to $\infty$ ), which takes into account both internal and external margins. See Chetty et al. (2011, Table 1) and Ljungqvist and Sargent (2011) for more details on the range.

${ }^{24}$ Figure 1 shows year-to-quarter changes. While Figures 3-6 on model dynamics show deviations from the steady state, the implications of these figures are similar even after they are transformed into year-to-quarter changes.
} 
the real wage are consistent with Figure 1. Moreover, Figure 3 shows that the house price, $q_{t}$, increases much more than aggregate output, $y_{t}$, during a housing boom in the model, which is consistent with the observation that house prices often appreciated more strongly than output growth during past housing booms.

Among the stylized features of housing-market boom-bust cycles summarized in Section 2.1, the model fails to replicate only the significant declines in real wage growth rates after the ends of booms. To replicate this observation, the model needs some mechanism that reduces labour demand after housing busts. Note that such an extension of the model is likely to amplify boom-bust cycles in the model, because the real interest rate during a boom would be lower if savers expected a deeper recession after the boom.

\subsection{The necessity of heterogeneous household beliefs for generat- ing boom-bust cycles}

To clarify the role of heterogeneous household beliefs in generating expectation-driven boombust cycles, Figure 3 shows in the dashed lines the impulse responses to an ex-post wrong public signal of future technological progress when both mortgage borrowers and savers consider the signal accurate (i.e., $\nu_{A}^{\prime}=0$ and $\nu_{A}^{\prime \prime}=0$ ). The comparison between the solid lines and the dashed lines demonstrates that the existence of non-optimistic savers along with optimistic mortgage borrowers is crucial to generate expectation-driven boom-bust cycles. ${ }^{25} \mathrm{As}$ shown in the dashed lines, the real interest rate for mortgage debt, $r r_{t}$, rises in period 3 when savers are optimistic about technological progress in period 4, since savers reduce savings by expecting high future income. A resulting rise in the cost of borrowing discourages mortgage borrowers from increasing housing investments. Thus, no expectation-driven housing boom occurs with homogeneous household expectations. No increase in aggregate output occurs, either, because mortgage borrowers do not work more to raise internal funds for increasing their housing investments. Also, optimistic savers reduce investments in capital to increase their current consumption in this case. This effect contributes to no increase in aggregate output. ${ }^{26}$

\footnotetext{
${ }^{25}$ An unreported sensitivity analysis shows that expectation-driven boom-bust cycles do not occur when: all households are savers; part of savers consider the ex-post wrong public signal accurate; but the other savers regard the signal as a noise. Thus, the existence of borrowing constraints on mortgage borrowers is necessary, but not sufficient, for generating expectation-driven boom-bust cycles.

${ }^{26}$ Note that the reaction of the economy after period 4 is much stronger than the reaction before period 4 in the dashed lines of Figure 3, because a higher financing cost of housing due to a rise in the real interest rate makes mortgage borrowers sell their houses before period 4 . When the expected shock is not realized in period 4, mortgage borrowers increase their labour supply to replenish their housing stock. A resulting increase in aggregate labour supply lowers the real wage significantly after period 4 , since there is no positive technological shock. This wage effect, in turn, reduces mortgage borrowers' income, leading to more sales of their houses and a further increase in their labour supply to support their consumption in period 4 . This amplification between a lower real wage and higher labour supply results in a large fluctuation in the economy after period 4. Lacking this amplification mechanism, the reaction of the economy before period 4 is much smaller than the reaction after period 4.
} 


\subsection{Dynamics with ex-post correct public signals}

Figure 4 compares the impulse responses to ex-post wrong and correct public signals of future technological progress $\left(\left(z_{A, 0}, \epsilon_{A, 4}\right)=(1,0)\right.$ and $\left.\left(z_{A, 0}, \epsilon_{A, 4}\right)=(1,1)\right)$, when mortgage borrowers consider the signal accurate, but savers regard the signal as a noise (i.e., $\nu_{A}^{\prime}=\infty$ and $\left.\nu_{A}^{\prime \prime}=0\right)$. When the signal turns out to be correct, the real house price remains above the steady-state value after period 4, confirming the optimistic expectations of mortgage borrowers.

\subsection{Effect of higher availability of mortgage debt on housing- market boom-bust cycles}

In addition, Figure 5 shows that less stringent borrowing constraints on mortgage borrowers due to an increase in $m$ amplify boom-bust cycles. This result contrasts with the earlier result in the literature that house-price dynamics are insensitive to the tightness of borrowing constraints, as shown by Iacoviello (2005). The key reason for this result is that the stochastic discount factor for savers, $E_{t}^{\prime}\left[\beta^{\prime} c_{t}^{\prime} / c_{t+1}^{\prime}\right]$, rises whereas that for mortgage borrowers, $E_{t}^{\prime \prime}\left[\beta^{\prime \prime} c_{t}^{\prime \prime} / c_{t+1}^{\prime \prime}\right]$, drops in period 3 because of heterogeneous expectations. ${ }^{27}$ To see this, note that the housing investment by each mortgage borrower satisfies the following first-order condition:

$$
\frac{\gamma c_{t}^{\prime \prime}}{h_{t}^{\prime \prime}}=q_{t}-\frac{m E_{t}^{\prime} q_{t+1}}{r r_{t}}-E_{t}^{\prime \prime}\left[\frac{\beta^{\prime \prime} c_{t}^{\prime \prime}\left(q_{t+1}-m E_{t}^{\prime} q_{t+1}\right)}{c_{t+1}^{\prime \prime}}\right]
$$

where the left-hand side is the marginal utility from housing in terms of consumption. The difference between the first two terms on the right-hand side is the downpayment required per unit of housing investment. The last term on the right-hand side is the expected discounted value of home equity per housing investment for a mortgage borrower in the next period. Thus, the right-hand side is the effective marginal cost of housing investments for mortgage borrowers. Since $E_{t}^{\prime}\left[\beta^{\prime} c_{t}^{\prime} / c_{t+1}^{\prime}\right]=1 / r r_{t}$ in equilibrium, an increase in $m$ reduces the cost of housing investments for mortgage borrowers significantly in period 3 , given a rise in $E_{t}^{\prime}\left[\beta^{\prime} c_{t}^{\prime} / c_{t+1}^{\prime}\right]$ and a drop in $E_{t}^{\prime \prime}\left[\beta^{\prime \prime} c_{t}^{\prime \prime} / c_{t+1}^{\prime \prime}\right]$. This effect amplifies a housing boom in period 3 , which spills over to earlier periods.

\section{$5 \quad$ Housing-market boom-bust cycles with sticky prices and heterogeneous labour supply elasticities}

In this section, I use the model with sticky prices (i.e., $\chi>0$ ) to discuss the reason for the low policy interest rates observed during past housing booms as indicated by Figure 1. For all dynamics shown below, mortgage borrowers regard as accurate an ex-post wrong

\footnotetext{
${ }^{27}$ These movements in $E_{t}^{\prime}\left[\beta^{\prime} c_{t}^{\prime} / c_{t+1}^{\prime}\right]$ and $E_{t}^{\prime \prime}\left[\beta^{\prime \prime} c_{t}^{\prime \prime} / c_{t+1}^{\prime \prime}\right]$ can be confirmed by Figure 4 . Note that savers and mortgage borrowers expect the public signal to be wrong and correct, respectively.
} 
public signal of future technological progress, but savers consider the signal as a noise (i.e., $\left.\left(z_{A, 0}, \epsilon_{A, 4}, \nu_{A}^{\prime}, \nu_{A}^{\prime \prime}\right)=(1,0, \infty, 0)\right)$.

\subsection{Parameter specification}

The monetary policy rule coefficients, $\phi_{\pi}, \phi_{Y}$ and $\phi_{R}$, are set to $1.53,0.93$, and 0.73 , in order, as estimated by Rudebusch (2002) for the U.S. ${ }^{28}$ The probability of price adjustment by intermediate-input producers, $1-\chi$, is set to 0.5 , so that producers change their prices every two quarters on average. This value is consistent with the recent microdata analysis on the frequency of price changes, such as Bils and Klenow (2004) and Nakamura and Steinsson (2008) for the U.S., Amirault, Kwan, and Wilkinson (2005) for Canada, and Bunn and Ellis (2009) for the U.K. ${ }^{29}$

It turns out to be necessary to assume a higher labour supply elasticity for mortgage borrowers than for savers to generate co-movement between the house price and aggregate output if sticky prices and a Taylor rule are introduced into the model. ${ }^{30}$ This assumption, however, is consistent with the recent literature on heterogeneous labour supply among different age cohorts. For example, Jaimovich and Siu (2009) find that the volatility of labour supply tends to decline with the ages of workers in developed countries, except volatile labour supply of those who are in retirement ages. Also, Campbell and Hercowitz (2004) take into account the difference in labour supply between mortgage borrowers and savers, who tend to be young and old, respectively, by assuming that savers do not supply labour in their model.

I calibrate the inverses of labour supply elasticities, $\xi$, of mortgage borrowers and savers to the standard deviations of detrended hours worked of young and old workers divided by the standard deviation of detrended GDP, given the other parameter values. The data on the hours worked of young and old workers are used as proxies for the hours worked of mortgage borrowers and savers, respectively. Given the difficulty in identifying the frequency of public signals that cause heterogeneous household expectations in data, I use the model without public signals, $z_{A, t}$, for the calibration exercise to set realistic values of labour supply

\footnotetext{
${ }^{28}$ In fact, Rudebusch argues that a positive estimate of $\phi_{R}$ is misspecified, because it implies a large amount of forecastable variation in policy interest rates in contradiction to data. Even though I include $\phi_{R}$ in this paper as is standard in the literature, the results shown below are robust to Rudebusch's estimates of $\phi_{\pi}$ and $\phi_{Y}$ without including $\phi_{R}\left(\phi_{\pi}=1.24, \phi_{Y}=0.33\right.$, and $\left.\phi_{R}=0\right)$.

${ }^{29}$ Bils and Klenow find that half of prices in CPI microdata last 5.5 months or less, even after excluding temporary price cuts (sales). Nakamura and Steinsson report a similar finding in PPI microdata when sales are included. Amirault, Kwan, and Wilkinson (2005) find that half of Canadian firms changed prices at least once every three months from July 2002 to March 2003 in a survey conducted by the Bank of Canada. Also, Bunn and Ellis (2009) report that the average interval of price changes in U.K. monthly CPI microdata is 5.3 months for all items and 6.7 months for all items excluding temporary discounts. Recent new-Keynesian models take into account the high frequency of price adjustment observed in micro data. See Eichenbaum and Fisher (2007) and Altig et al. (2011) for more details.

${ }^{30}$ If labour supply elasticity is homogeneous in the model with sticky prices, then savers' labour supply affects aggregate labour supply so strongly that aggregate labour supply drops during a housing boom. This effect causes a negative correlation between aggregate output and the real house price.
} 
elasticities. Note that the model without public signal is very similar to Iacoviello's (2005) model, so the calibration result is based on a standard business cycle model with housing. The calibration yields $\xi=1.03$ for savers and $\xi=0.01$ for mortgage borrowers. ${ }^{31}$ See Table 4 for the comparison of the moments of aggregate variables between the calibrated model and the data.

\subsection{Model dynamics}

Figure 6 shows the impulse responses to an ex-post wrong public signal of future technological progress with heterogeneous household beliefs in the flexible price case (the solid lines) and the case with sticky prices and heterogeneous labour supply elasticities (the dashed lines). The following features of the dashed lines are largely consistent with Figure 1: aggregate output, investment, consumption, and hours worked co-move with the real house price; procyclical aggregate labour supply is driven by the labour supply of mortgage borrowers; and the inflation rate, the policy interest rate, the real interest rate, and the real wage drop temporarily during a housing boom. ${ }^{32}$

The underlying mechanism for the dynamics of aggregate quantity variables is as same as described in the previous section. The intuition for temporary declines in price variables during a boom is as follows. As in the flexible price case, aggregate labour supply and savings rise during a housing boom, lowering the real wage and the real interest rate. Given sticky prices, a resulting decline in the real marginal cost of production leads to a drop in the inflation rate through the pricing behaviour of producers. ${ }^{33}$ In response, the central bank cuts the policy interest rate to stabilize the inflation rate, given the Taylor rule. This result implies that the low policy interest rates observed during housing booms are consistent with the existence of over-optimism as the cause of boom-bust cycles.

In the model, a housing bust occurs subsequently when the signaled technological progress is not realized in period 4. Resulting declines in aggregate labour supply and savings raise the real wage and the real interest rate. Hence the inflation rate rises with the real marginal cost of production, and so does the policy interest rate. This result replicates the rises in CPI inflation rates, policy interest rates, real interest rates, and real wage growth rates observed around the ends of past housing booms as shown in Figure 1. The model still fails to replicate the significant declines in real wage growth rates observed after the ends of booms, as in the

\footnotetext{
${ }^{31}$ The calibration chooses the values of $\xi$ for mortgage borrowers and savers that minimize the sum of squares of percent gaps between the two moments in the model and the data. In the data, both hours worked and GDP are log-linearly detrended. I find it difficult to apply gradient-based solution methods to this minimization problem, because of a flat surface of the objective function of the problem. Instead, I use grid search. The grid points are $\{0.01,0.02, \ldots, 2\}$ for each type of household. There is no significant improvement in the match between the model and the data even if I set a smaller lower bound for the value of $\xi$ in the grid points.

${ }^{32}$ If $\chi$ is high, then the inflation rate does not fluctuate much in the model. In this case, the policy interest rate becomes more responsive to output, given the values of $\phi_{\pi}$ and $\phi_{Y}$. This effect prevents simultaneous boom-bust cycles in the house price and aggregate output.

${ }^{33}$ This relationship between the marginal cost of production and the inflation rate appears in the newKeynesian Phillips curve implied by the maximization problem for intermediate-input producers.
} 
flexible price case. As discussed above, this result indicates existence of some mechanism that reduces labour demand after housing busts. A further investigation into this question is left for future research.

Finally, the amplitude of the boom-bust cycle in the current case is larger than in the benchmark case because of heterogeneous labour supply elasticities. The low labour supply elasticity of savers makes aggregate labour supply more sensitive to the labour supply of mortgage borrowers. Resulting larger fluctuations in aggregate labour supply amplify the boom-bust cycle. ${ }^{34}$

\section{Conclusions}

In this paper, I show that over-optimism of mortgage borrowers can cause boom-bust cycles, if mortgage borrowers are credit-constrained and savers who supply mortgage loans to mortgage borrowers do not share the over-optimism. Also, in the presence of price stickiness, the model generates a low policy interest rate during a housing boom as an endogenous reaction to a low inflation rate, given a Taylor rule. These results are consistent with the stylized features of housing-market boom-bust cycles observed in developed countries. In addition, a policy experiment shows that less stringent borrowing constraints on mortgage borrowers amplify boom-bust cycles.

In the model, I focus on over-optimism of future technological progress as the source of business fluctuations. To replicate more detailed observations than the stylized features of housing-market boom-bust cycles, it would be necessary to disentangle fundamental shocks from the effect of over-optimism in data and analyze the effect of fundamental shocks. This work is left for future research.

\footnotetext{
${ }^{34}$ Heterogeneous labour supply elasticities also reduce the difference between increases in aggregate output and the house price. In the current case, savers' labour supply is much less elastic than mortgage borrowers' labour supply, so a decline in savers' labour supply does not offset much an increase in mortgage borrowers' labour supply during a boom. As a result, fluctuations in aggregate output increase. Fluctuations in the house price does not increase as much, however, because they are driven not only by current aggregate output through current consumption, but also by a lowered real interest rate due to non-optimistic expectations of savers during a boom.
} 


\section{Acknowledgement}

I thank Jason Allen, James Chapman, Jonathan Chiu, Ian Christensen, Sharon Kozicki, Miguel Molico, Makoto Nirei, Malik Shukayev, Yaz Terajima for their comments. Tom Carter and David Xiao Chen provided excellent research assistance. 


\section{Appendices}

\section{A Data appendix}

\section{A.1 Figures 1}

Ahearne et al. (2005) use real house prices for determining the peaks of housing booms. See the data appendix of their paper for more details on identification of the peaks of housing booms during past boom-bust cycles.

Real house price growth rates are calculated from the data used by Desroches and Francis (2007), which extends the database constructed by Bordo and Jeanne (2002) with BIS data.

Real GDP growth rates come from the OECD database. The series are based on seasonally adjusted real GDP. The rates are annualized quarterly growth rates. For Germany, unified German data is used whenever possible. If not available, West German data is used. This is the same for the following data.

Total CPI inflation rates come from the OECD database. These series give year-toquarter changes in the price index as a percentage.

Short-term nominal interest rates are 3-month nominal money-market rates taken from the OECD database. These rates are normally highly correlated with the target rate adopted by the central bank. If short-term interest rates are not available from the OECD database, this paper uses the money market rates from the IMF database. For a given peak, this paper always uses a single source per country. This paper does this by counting the number of observations available from each source for that country around that peak and choosing the source to maximize this count. All short-term rates are expressed in percentage points on an annualized basis. Short-term real interest rates are ex-post rates, which are the differences between short-term nominal interest rates and realized total CPI inflation rates.

Hours worked are calculated as the product of two series from the OECD database: the total number of workers in the economy and the hours worked per employee. The growth rate is expressed in percentage points on a year-to-quarter basis. Belgium, Denmark, Spain, and Switzerland do not have data available at quarterly frequency. For these countries, this paper computes year-over-year growth rates, then interpolate quarterly values by estimating a cubic spline, using the year-over-year results as year-end values.

The numbers of employed people for different age cohorts are from the OECD database. The data have a few discontinuous country-year points due to changes in data coverage. These discontinuous points are excluded from the sample.

Hourly earnings in manufacturing are seasonally adjusted series from the OECD database. Real hourly earnings are divided by the total CPI, and the figure shows year-to-quarter changes. 


\section{A.2 Table 2 and Figure 2}

The real house price growth rate is the first-order log difference of the nationwide house price index from the Federal Housing Finance Agency divided by the GDP deflator. The Index of Consumer Expectations for young households are the average of the index for 18-34 years old (ice_a1834) and that for 35-44 years old (ice_a3544) in the Reuters/University of Michigan Surveys of Consumers weighted by the numbers of householders in corresponding age groups from Table HH-3, the March CPS, U.S. Census Bureau. The number of householders in each age group in Table HH-3 is annual. This series is converted into a quarterly series by linear interpolation. The Index of Consumer Expectations for old households are similarly constructed from ice_a4554, ice_a4564 and ice_a6597. "Difference between young and old" in the figure is the difference of the index for young households from the index for old households. Real GDP is available from the Bureau of Economic Analysis. The ex-post real interest rate is the 90-day treasury bill rate minus the rate of change in the GDP deflator between the current and the next quarters.

\section{A.3 The standard deviations of hours worked of young and old workers and the demand components of GDP in the U.S.}

Average hours worked for young and old workers are taken from the March CPS, U.S. Census Bureau. Annual data series are available from cps.ipums.org/cps (Miriam King, Steven Ruggles, Trent Alexander, Donna Leicach, and Matthew Sobek. Integrated Public Use Microdata Series, Current Population Survey: Version 2.0. [Machine-readable database]. Minneapolis, MN: Minnesota Population Center [producer and distributor], 2004). Quarterly data series are constructed by linear interpolation. hours worked are log-linearly detrended when calculating standard deviations. The sample period is for 1980:1-2006:4.

Quarterly GDP and its demand components are available from the Bureau of Economic Analysis. The real values of GDP, private consumption, private investment are log-linearly detrended when calculating standard deviations. The sample periods are for 1980:1-2008:2.

\section{B The proof for no capital holding by mortgage bor- rowers around the steady state}

In this section, I show that mortgage borrowers do not buy capital from savers in the neighbourhood of the deterministic steady state even if they can. If savers and mortgage borrowers can trade capital in a competitive market, then the flow of funds constraint and the law of motion for capital for savers (i.e., Eqs. (9) and (10), respectively) are modified to:

$$
\begin{gathered}
c_{t}^{\prime}+\frac{\eta_{K}}{2}\left(\frac{i_{t}^{\prime}}{s_{t-1}^{\prime}}\right)^{2} s_{t-1}^{\prime}+q_{t}\left(h_{t}^{\prime}-h_{t-1}^{\prime}\right)+b_{t}^{\prime}=w_{t} l_{t}^{\prime}+v_{t} x_{t}^{\prime}+r_{K, t} s_{t-1}^{\prime}+\frac{R_{t-1}}{\pi_{t}} b_{t-1}^{\prime}+\Gamma_{t}, \\
s_{t}^{\prime}=i_{t}^{\prime}-x_{t}^{\prime}+(1-\delta) s_{t-1}^{\prime},
\end{gathered}
$$


where: $v_{t}$ is the competitive market price of capital; and $x_{t}^{\prime}$ is the amount of capital that savers sell in the market. The value of $x_{t}^{\prime}$ must be non-negative. Similarly, the flow of funds constraint for mortgage borrowers is modified as follows with the law of motion for their capital:

$$
\begin{gathered}
c_{t}^{\prime \prime}+q_{t}\left(h_{t}^{\prime \prime}-h_{t-1}^{\prime \prime}\right)+b_{t}^{\prime \prime}+v_{t} x_{t}^{\prime \prime}=w_{t} l_{t}^{\prime \prime}+\frac{R_{t-1}}{\pi_{t}} b_{t-1}^{\prime \prime}+r_{K, t} s_{t-1}^{\prime \prime} \\
s_{t}^{\prime \prime}=x_{t}^{\prime \prime}+(1-\delta) s_{t-1}^{\prime \prime},
\end{gathered}
$$

where $x_{t}^{\prime \prime}$ is the amount of capital that mortgage borrowers buy in the market and $s_{t}^{\prime \prime}$ is the stock of capital held by mortgage borrowers at the end of period $t$. The value of $x_{t}^{\prime \prime}$ must be non-negative. Without loss of generality, I do not assume any borrowing constraint on $x_{t}^{\prime \prime}$, because mortgage borrowers set the value of $x_{t}^{\prime \prime}$ to zero even without a borrowing constraint, as shown below. The market clearing condition for the capital market is:

$$
\mu x_{t}^{\prime}=(1-\mu) x_{t}^{\prime \prime} .
$$

With Eqs. (24) and (25), the first-order condition regarding $x_{t}^{\prime}$ and the envelope theorem imply:

$$
\begin{aligned}
& \frac{v_{t}}{c_{t}^{\prime}}=\lambda_{t}^{\prime}+\kappa_{t}^{\prime}, \\
& \lambda_{t}^{\prime}=\beta^{\prime} E_{t}^{\prime}\left\{\lambda_{t+1}^{\prime}(1-\delta)+\frac{1}{c_{t+1}^{\prime}}\left[\frac{\eta_{K}}{2}\left(\frac{i_{t}}{s_{t-1}}\right)^{2}+r_{K, t}\right]\right\},
\end{aligned}
$$

where $\lambda_{t}^{\prime}$ and $\kappa_{t}^{\prime}$ are the Lagrange multipliers for Eq. (25) and $x_{t}^{\prime} \geq 0$, respectively. Now suppose that $\kappa_{t}^{\prime}=0$ at the deterministic steady state. Given $\eta_{K}=2 / \delta$ as specified in Section 5.1, Eqs. (29) and (30) imply:

$$
v=\frac{r_{K}+\delta}{1-\beta^{\prime}(1-\delta)}
$$

where variables without subscripts denote steady state values.

With Eqs. (26) and (27), the first-order condition regarding $x_{t}^{\prime \prime}$ and the envelope theorem imply:

$$
\frac{v_{t}}{c_{t}^{\prime \prime}}=\beta^{\prime \prime} E_{t}^{\prime \prime}\left[\frac{r_{K, t+1}+v_{t+1}(1-\delta)}{c_{t+1}^{\prime \prime}}\right]+\kappa_{t}^{\prime \prime}
$$

where $\kappa_{t}^{\prime \prime}$ is the Lagrange multipliers for $x_{t}^{\prime \prime} \geq 0$. At the steady state, $\kappa^{\prime \prime}>0$ because:

$$
\begin{aligned}
v-\beta^{\prime \prime}\left[r_{K}+v(1-\delta)\right] & =\frac{\left[1-\beta^{\prime \prime}(1-\delta)\right]\left(r_{K}+\delta\right)}{1-\beta^{\prime}(1-\delta)}-\beta^{\prime \prime} r_{K} \\
& >r_{K}+\delta-\beta^{\prime \prime} r_{K} \\
& >0 .
\end{aligned}
$$


The second inequality holds given the assumption that $\beta^{\prime \prime}<\beta^{\prime}$. Thus, $x^{\prime \prime}=0$ at the deterministic steady state. Accordingly, the conjecture that $\kappa^{\prime}=0$ is verified, because Eq. (28) implies $x^{\prime}=0$, which satisfies $x^{\prime} \geq 0$. Given the continuity of the model, $x_{t}^{\prime}=x_{t}^{\prime \prime}=0$ in the neighbourhood of the deterministic steady state.

\section{The numerical solution method}

The system of log-linearized equilibrium conditions takes the following form:

$$
\begin{aligned}
A\left[E \zeta_{t+1}^{T}, E_{1} \epsilon_{A, t+1}, E_{2} \epsilon_{A, t+1}, \hat{k k_{t+1}^{T}}, E_{1} \hat{x}_{1, t+1}^{T},\right. & \left.E_{2} \hat{x}_{2, t+1}^{T}, E_{1} \hat{p p}_{t+1}^{T}, E_{2} \hat{p p}_{t+1}^{T}\right]^{T} \\
& =B\left[\zeta_{t}^{T}, \epsilon_{A, t}, \hat{k k_{t}^{T}}, \hat{x}_{1, t}^{T}, \hat{x}_{2, t}^{T}, \hat{p p_{t}^{T}}\right]^{T}
\end{aligned}
$$

where: $A$ and $B$ are constant matrices; $E_{1}=E^{\prime}$ and $E_{2}=E^{\prime \prime}$, which are the subjective expectation operators for savers and mortgage borrowers, respectively; $\zeta_{t}=\left[z_{A, t}, \ldots, z_{A, t-\tau+1}\right]^{T}$, where $z_{A, t}$ is the public signal of $\epsilon_{A, t+\tau} ; k k_{t+1}=\left[A_{t}, R_{t}, k_{t}^{\prime}, b_{t}^{\prime}, h_{t}^{\prime}, b_{t}^{\prime \prime}, h_{t}^{\prime \prime}\right]^{T}$, which is the vector of endogenous state variables determined at period $t ; x_{1, t}=\left[c_{t}^{\prime}, l_{t}^{\prime}, i_{t}^{\prime}\right]^{T}$ and $x_{2, t}=\left[c_{t}^{\prime \prime}, l_{t}^{\prime \prime}\right]^{T}$, which are the vectors of jump choice variables for savers and mortgage borrowers, respectively; $p p_{t}=\left[\pi_{t}, q_{t}, r_{K, t}, w_{t}, f_{t}, y_{t}\right]^{T}$, which is the vector of jump aggregate variables and market prices; and the hat symbol ( ${ }^{\wedge}$ ) denotes the log deviations of the vectors from the deterministic steady state. (The definitions of these vectors are for the sticky price case. The vectors for the flexible price case can be similarly defined by including $r r_{t}$ in $p p_{t}$ and removing $R_{t}$ and $\pi_{t}$.) The expectation operator to $\zeta_{t+1}$ is $E$, which is the common expectation operator between the two types of households, as there is no disagreement on the likelihood of future signals. The matrices $A$ and $B$ can be written as:

$$
\begin{aligned}
A & =\left[\begin{array}{cccccccc}
A_{\zeta} & A_{1, \epsilon} & A_{2, \epsilon} & 0 & 0 & 0 & 0 & 0 \\
0 & 0 & 0 & A_{k k} & A_{1, x} & A_{2, x} & A_{1, p p} & A_{2, p p}
\end{array}\right] \\
B & =\left[\begin{array}{cccccc}
B_{\zeta} & 0 & 0 & 0 & 0 & 0 \\
0 & B_{\epsilon} & B_{k k} & B_{1, x} & B_{2, x} & B_{p p}
\end{array}\right] .
\end{aligned}
$$

The upper partition of rows of $A$ and $B$ corresponds to the subjective expectations of $\epsilon_{A, t+1}$ defined by Eqs. (16) and (17) and the law of motion of public signals (i.e., $E \zeta_{t+1}(1)=$ $E z_{A, t+1}=0$ and $E \zeta_{t+1}(n)=z_{A, t-n+2}=\zeta_{t}(n-1)$ for $n=2,3, \ldots, \tau$, where $\zeta_{t}(n)$ denotes the $n$ th element of the vector $\zeta_{t}$ ). The lower partition of rows corresponds to the other equilibrium conditions, including the law of motion of technology (i.e., $\left.\ln \left(A_{t}\right)=\rho_{A} \ln \left(A_{t-1}\right)+\epsilon_{A, t}\right)$.

Conjecture that the solution takes the following state-space form:

$$
\left[\begin{array}{c}
\hat{x}_{1, t} \\
\hat{x}_{2, t} \\
\hat{p p_{t}} \\
\hat{k k_{t+1}}
\end{array}\right]=\left[\begin{array}{ccc}
Q_{1} & R_{1} & S_{1} \\
Q_{2} & R_{2} & S_{2} \\
G & H & J \\
U & V & W
\end{array}\right]\left[\begin{array}{c}
\hat{k} k_{t} \\
\epsilon_{A, t} \\
\zeta_{t}
\end{array}\right],
$$


and then substitute the conjectured solution form (B.4) into the system of log-linearized equilibrium conditions (B.1) to obtain the conditions that must be satisfied by the solution. I start from finding the conditions for the coefficient matrices for $\hat{k k_{t}}$ and $\epsilon_{A, t}$ (i.e., $Q_{i}$ and $R_{i}$ for $i=1,2$ and $G, H, U$ and $\left.V\right)$. As $\hat{k k_{t}}$ and $\epsilon_{A, t}$ do not appear in the upper partition of rows of $A$ and $B$ shown in Eq. (B.3), I need to consider only the conditions associated with the lower partition of rows of $A$ and $B$. These conditions imply:

$$
\left[\begin{array}{c}
A_{k k} \\
A_{1, x} \\
A_{2, x} \\
A_{1, p p} \\
A_{2, p p}
\end{array}\right]^{T}\left[\begin{array}{ccccc}
I & 0 & 0 & 0 & 0 \\
Q_{1} & R_{1} & 0 & S_{1} & 0 \\
Q_{2} & 0 & R_{2} & 0 & S_{2} \\
G & H & 0 & J & 0 \\
G & 0 & H & 0 & J
\end{array}\right]\left[\begin{array}{c}
U \hat{k k}_{t}+V \epsilon_{A, t}+W \zeta_{t} \\
E_{1} \epsilon_{A, t+1} \\
E_{2} \epsilon_{A, t+1} \\
E_{1} \zeta_{t+1} \\
E_{2} \zeta_{t+1}
\end{array}\right]=\left[\begin{array}{c}
B_{\epsilon} \\
B_{k k} \\
B_{1, x} \\
B_{2, x} \\
B_{p p}
\end{array}\right]^{T}\left[\begin{array}{ccc}
0 & 1 & 0 \\
I & 0 & 0 \\
Q_{1} & R_{1} & S_{1} \\
Q_{2} & R_{2} & S_{2} \\
G & H & J
\end{array}\right]\left[\begin{array}{c}
\hat{k} k_{t} \\
\epsilon_{A, t} \\
\zeta_{t}
\end{array}\right],
$$

where $I$ is the identity matrix of size equal to the number of elements of $k k_{t+1}$. Note that $\hat{k k_{t+1}}, E_{1} \hat{x}_{1, t+1}, E_{2} \hat{x}_{2, t+1}, E_{1} \hat{p p} p_{t+1}, E_{2} \hat{p p}_{t+1}, \hat{x}_{1, t}, \hat{x}_{2, t}, \hat{p p_{t}}$ are substituted by the conjectured solution form. As $E_{1} \epsilon_{A, t+1}, E_{2} \epsilon_{A, t+1}, E_{1} \zeta_{t+1}$ and $E_{2} \zeta_{t+1}$ are linear to $\zeta_{t}$ independently of $\hat{k k_{t}}$ and $\epsilon_{A, t}$ by assumption, Eq. (B.5) implies that:

$$
\left[\begin{array}{l}
A_{k k} \\
A_{1, x} \\
A_{2, x} \\
A_{1, p p} \\
A_{2, p p}
\end{array}\right]^{T}\left[\begin{array}{c}
I \\
Q_{1} \\
Q_{2} \\
G \\
G
\end{array}\right]\left[\begin{array}{ll}
U & V
\end{array}\right]=\left[\begin{array}{c}
B_{\epsilon} \\
B_{k k} \\
B_{1, x} \\
B_{2, x} \\
B_{p p}
\end{array}\right]^{T}\left[\begin{array}{cc}
0 & 1 \\
I & 0 \\
Q_{1} & R_{1} \\
Q_{2} & R_{2} \\
G & H
\end{array}\right]
$$

so that the equality in Eq. (B.5) holds for all $\hat{k k_{t}}$ and $\epsilon_{A, t}$.

Now note that, if there is no public signal in the model, then the log-linearized equilibrium system is reduced to $E \epsilon_{A, t+1}=0$ and:

$$
\begin{aligned}
{\left[A_{k k}, A_{1, x}, A_{2, x}, A_{1, p p}+\right.} & \left.A_{2, p p}\right]\left[\hat{k}_{t+1}^{T}, E \hat{x}_{1, t+1}^{T}, E \hat{x}_{2, t+1}^{T}, E \hat{p p_{t+1}^{T}}\right]^{T} \\
& =\left[B_{\epsilon}, B_{k k}, B_{1, x}, B_{2, x}, B_{p p}\right]\left[\epsilon \epsilon_{A, t}, \hat{k k_{t}^{T}}, \hat{x}_{1, t}^{T}, \hat{x}_{2, t}^{T}, \hat{p p_{t}^{T}}\right]^{T} .
\end{aligned}
$$

If I substitute into this system a conjectured solution form for the case without public signals:

$$
\left[\begin{array}{c}
\hat{x}_{1, t} \\
\hat{x}_{2, t} \\
\hat{p p}_{t} \\
\hat{k k_{t+1}}
\end{array}\right]=\left[\begin{array}{cc}
Q_{1} & R_{1} \\
Q_{2} & R_{2} \\
G & H \\
U & V
\end{array}\right]\left[\begin{array}{l}
k k_{t} \\
\epsilon_{A, t}
\end{array}\right],
$$

then I obtain an identical condition to Eq. (B.6). As the model without public signals is a standard rational expectation equilibrium model, the standard method described by Klein (2000) can solve Eq. (B.6) for $Q_{i}$ and $R_{i}$ for $i=1,2$ and $G, H, U$ and $V$. Thus, the value of 
these matrices are unique if the model without public signals has unique solution. See Klein (2000) for the conditions for the uniqueness.

Note that this equivalence result depends on the assumption that heterogeneous subjective beliefs on future technological shocks are generated only by the exogenous public signals, $\zeta_{t}$. If $\hat{k}_{t}$ and $\epsilon_{A, t}$ also affected the subjective beliefs, then the coefficients for $\hat{k k_{t}}$ and $\epsilon_{A, t}$ would not be zero in the upper partition of rows of $A$ and $B$ shown in Eq. (B.3). In this case, the solution for $Q_{i}$ and $R_{i}$ for $i=1,2$ and $G, H, U$ and $V$ in the model without public signals would not be identical to those in the model with public signals, because the upper partition is replaced by $E \epsilon_{A, t+1}=0$ if without public signals.

Next, I derive the conditions that must be satisfied by $S_{1}, S_{2}, J$ and $W$. Given that Eqs. (16) and (17) imply that $E_{1} \epsilon_{A, t+1}=E^{\prime} \epsilon_{A, t+1}=\left\{\sigma_{A}^{2} /\left[\sigma_{A}^{2}+\left(\nu_{A}^{\prime}\right)^{2}\right]\right\} z_{A, t-\tau+1}$ and $E_{2} \epsilon_{A, t+1}=$ $E^{\prime \prime} \epsilon_{A, t+1}=\left\{\sigma_{A}^{2} /\left[\sigma_{A}^{2}+\left(\nu_{A}^{\prime \prime}\right)^{2}\right]\right\} z_{A, t-\tau+1}$, the coefficients for $z_{A, t-\tau+1}$ in Eq. (B.5) imply:

$$
\left[A_{k k}+\sum_{i=1}^{2}\left(A_{i, x} Q_{i}+A_{i, p} G\right)\right] w_{\tau}+\sum_{i=1}^{2}\left(A_{i, x} R_{i}+A_{i, p} H\right) \psi_{i}-\left[B_{1, x}, B_{2, x}, B_{p}\right]\left[\begin{array}{c}
s_{1, \tau} \\
s_{2, \tau} \\
j_{\tau}
\end{array}\right]=0
$$

where $\psi_{1} \equiv \sigma_{A}^{2} /\left[\sigma_{A}^{2}+\left(\nu_{A}^{\prime}\right)^{2}\right], \psi_{2} \equiv \sigma_{A}^{2} /\left[\sigma_{A}^{2}+\left(\nu_{A}^{\prime \prime}\right)^{2}\right], W \equiv\left[w_{1}, \ldots, w_{\tau}\right]$, and $s_{1, n}, s_{2, n}$ and $j_{n}$ are the column vectors of $S_{1}, S_{2}$ and $J$ similarly defined for $n=1, \ldots, \tau$, respectively. Thus:

$$
\left[w_{\tau}^{T}, s_{1, \tau}^{T}, s_{2, \tau}^{T}, j_{\tau}^{T}\right]^{T}=-\Phi^{-1} \sum_{i=1}^{2}\left(A_{i, x} R_{i}+A_{i, p} H\right) \psi_{i}
$$

where:

$$
\Phi \equiv\left[A_{k}+\sum_{i=1}^{2}\left(A_{i, x} Q_{i}+A_{i, p} G\right),-B_{1, x},-B_{2, x},-B_{p}\right]
$$

provided that $\Phi$ is invertible, which is the case for the parameter values considered in this paper.

Then, as $E z_{A, t+1}=0$ and $E_{1} \zeta_{t+1}=E_{2} \zeta_{t+1}=E \zeta_{t+1}=\left[0, z_{A, t}, z_{A, t-1}, \ldots, z_{A, t-\tau+2}\right]^{T}$, the coefficients for $z_{A, t-n+1}$ in Eq. (B.5) imply $\Phi\left[w_{n}^{T}, s_{1, n}^{T}, s_{2, n}^{T}, j_{n}^{T}\right]^{T}+\left[A_{1, x} s_{1, n+1}+A_{2, x} s_{2, n+1}+\right.$ $\left.\left(A_{1, p p}+A_{2, p p}\right) j_{n+1}\right]=0$ for $n=1, \ldots, \tau-1$. Thus, for $n=1, \ldots, \tau-1$ :

$$
\left[w_{n}^{T}, s_{1, n}^{T}, s_{2, n}^{T}, j_{n}^{T}\right]^{T}=-\Phi^{-1}\left[A_{1, x}, A_{2, x}, A_{1, p p}+A_{2, p p}\right]\left[s_{1, n+1}^{T}, s_{2, n+1}^{T}, j_{n+1}^{T}\right]^{T},
$$

which can be sequentially calculated from $n=\tau-1$ to $n=1$. Thus, if $\Phi$ is invertible, then the values of $W, S_{1}, S_{2}$ and $J$ are determined uniquely. Otherwise heterogeneous household beliefs generate multiple equilibria.

Intuitively speaking, the values of $W, S_{1}, S_{2}$, and $J$ are determined so that $\zeta_{t}$ affects household behaviour in the current period directly through each household's subjective expectation of the economy in the next period (which is summarized by $\sum_{i=1}^{2}\left(A_{i, x} R_{i}+A_{i, p} H\right) \psi_{i}$ for $n=\tau$ and $\left[A_{1, x}, A_{2, x}, A_{1, p p}+A_{2, p p}\right]\left[s_{1, n+1}^{T}, s_{2, n+1}^{T}, j_{n+1}^{T}\right]^{T}$ for $\left.n=1, \ldots, \tau-1\right)$ and then indirectly through a feedback loop between household behaviour and market prices that continues until the markets clear (which is summarized by $\Phi^{-1}$ ). 


\section{References}

[1] Ahearne, A.G., Ammer, J., Doyle, B.M., Kole, L.S., Martin, R.F., 2005. House Prices and Monetary Policy: A Cross-Country Study. Board of Governors of the Federal Reserve Systems International Finance Discussion Paper 841.

[2] Altig, D., Christiano, L.J., Eichenbaum, M., Lindé, J., 2011. Firm-Specific Capital, Nominal Rigidities and the Business Cycle. Review of Economic Dynamics 14, 225-247.

[3] Amirault, D., Kwan, C., Wilkinson, G., 2004. A Survey of the Price-Setting Behaviour of Canadian Companies. Bank of Canada Review (Winter), 29-40.

[4] Anufriev, M., Assenza, T., Hommes, C.H., Massaro, D., forthcoming. Interest Rate Rules and Macroeconomic Stability under Heterogeneous Expectations. Macroeconomic Dynamics.

[5] Assenza, T., Heemeijer, P., Hommes, C.H., Massaro, D., 2011. Individual Expectations and Aggregate Macro Behaviour. Mimeo, University of Amsterdam.

[6] Beaudry, P., Portier, F., 2004. An Exploration into Pigou's Theory of Cycles. Journal of Monetary Economics 51, 1183-1216.

[7] Beaudry, P., Portier, F., 2007. When can Changes in Expectations Cause Business Cycle Fluctuations in Neo-classical Settings? Journal of Economic Theory 127, 458-477.

[8] Bernanke, B., Gertler, M., 1999. Monetary Policy and Asset Price Volatility. Federal Reserve Bank of Kansas City Economic Review Fourth Quarter 1999, 17-51.

[9] Bernanke, B., Gertler, M., 2001. Should Central Banks Respond to Movements in Asset Prices? American Economic Review 91, 253-257.

[10] Bernanke, B., Gertler, M., Gilchrist, S., 1999. The Financial Accelerator in a Quantitative Business Cycle Framework, in: Taylor, J.B., Woodford, M. (Eds.), Handbook of Macroeconomics, Elsevier, Amsterdam, pp. 1341-1393.

[11] Bils, M., Klenow, P.J., 2004. Some Evidence on the Importance of Sticky Prices. Journal of Political Economy 112, 947-985.

[12] Bolton, P., Scheinkman, J.A., Xiong, W., 2006. Executive Compensation and ShortTermist Behaviour in Speculative Markets. Review of Economic Studies 73, 577-610.

[13] Bordo, M.D., Jeanne, O., 2002. Boom-Busts in Asset Prices, Economic Instability, and Monetary Policy. National Bureau of Economic Research Working Paper 8966.

[14] Borio, C., Lowe, P., 2002. Asset Prices, Financial and Monetary Stability: Exploring the Nexus. Bank for International Settlements Working Paper 114. 
[15] Branch, W., Evans, G., 2006. Intrinsic Heterogeneity in Expectation Formation. Journal of Economic Theory 127, 264-295.

[16] Branch, W., McGough, B., 2009. Monetary Policy in a New Keynesian Model with Heterogeneous Expectations. Journal of Economic Dynamics and Control 33, 1036-1051.

[17] Brunnermeier, M.K., Pedersen, L.H., 2009. Market Liquidity and Funding Liquidity. Review of Financial Studies 22, 2201-2238.

[18] Bunn, P., Ellis, C., 2009. Price-Setting Behaviour in the United Kingdom: a Microdata Approach. Bank of England Quarterly Bulletin (Q1), 28-36.

[19] Burnside, C., Eichenbaum, M., Rebelo, S., 2011. Understanding Booms and Busts in Housing Markets. National Bureau of Economic Research Working Paper 16734.

[20] Campbell, J.,R., Hercowitz, Z., 2004. Welfare Implications of the Transition to High Household Debt. Journal of Monetary Economics 56, 1-16.

[21] Cecchetti, S.G., Genberg, H., Lipsky, J., Wadhwani, S., 2000. Asset Prices and Central Bank Policy. International Center for Monetary and Banking Studies, Geneva.

[22] Chetty, R., Guren, A., Manoli, D., Weber, A., 2011. Are Micro and Macro Labor Supply Elasticities Consistent? A Review of Evidence on the Intensive and Extensive Margins. American Economic Review: Papers \& Proceedings 101, 471-475.

[23] Christiano, L., Ilut, C., Motto, R., Rostagno, M., 2010. Monetary Policy and Stock Market Booms, in Macroeconomic Challenges: the Decade Ahead, Federal Reserve Bank of Kansas City (Policy Symposium, Jackson Hole Wyoming).

[24] Cornea, A., Hommes, C.H., Massaro, D., 2012. Behavioral Heterogeneity in US Inflation. CeNDEF Working Paper 12-03, University of Amsterdam.

[25] Desroches, B., Francis, M., 2007. World Real Interest Rates: A Global Savings and Investment Perspective. Bank of Canada Working Paper 2007-16.

[26] Detken, C., Smets, F., 2004. Asset Price Booms and Monetary Policy. ECB Working Paper 364.

[27] De Grauwe, P., 2011. Animal Spirits and Monetary Policy. Economic Theory 47, 423457.

[28] Dupor, B., 2005. Stabilizing Non-Fundamental Asset Price Movements under Discretion and Limited Information. Journal of Monetary Economics 52, 727-747.

[29] Eichenbaum, M., Fisher, J.D.M., 2007. Estimating the Frequency of Price Reoptimization in Calvo-style Models. Journal of Monetary Economics 54, 2032-2047. 
[30] Favara, G., Song, Z., 2010. House Price Dynamics with Dispersed Information. Mimeo, International Monetary Fund and Swiss Finance Institute.

[31] Fisher, J.D.M., Gervais, M., 2011. Why Has Home Ownership Fallen Among the Young? International Economic Review 52, 883-912.

[32] Galí, J., 2011. The Return of the Wage Phillips Curve. Journal of the European Economic Association 9, 436-461.

[33] Geanakoplos, J., 2009. The Leverage Cycle, in: Acemoglu, D., Rogoff, K., Woodford, M., (Eds.), NBER Macroeconomics Annual 2009. University of Chicago Press, Chicago, pp. 1-65.

[34] Gilchrist, S., Leahy, J.V., 2002. Monetary Policy and Asset Prices. Journal of Monetary Economics 49, 75-97.

[35] Grant, C., 2007. Estimating Credit Constraints Among U.S. Households. Oxford Economic Papers 59, 583-605.

[36] Fostel, A., Geanakoplos, J., 2008. Leverage Cycles and the Anxious Economy. American Economic Review 98, 1211-1244.

[37] Fostel, A., Geanakoplos, J., 2011. Endogenous Leverage: VaR and Beyond. Cowles Foundation Discussion Paper 1800.

[38] Hajivassiliou, V.A., Ioannides, Y.M., 2007. Unemployment and Liquidity Constraints. Journal of Applied Econometrics 22, 479-510.

[39] Hart, O., Moore, J., 1994. A Theory of Debt Based on the Inalienability of Human Capital. Quarterly Journal of Economics 109, 841-879.

[40] Hommes, C.H., 2006. Heterogeneous Agent Models in Economics and Finance, in: Tesfatsion, L., Judd, K.L., (Eds.), Handbook of Computational Economics, Vol. 2. Elsevier, Amsterdam, pp. 1109-1186.

[41] Hong, H., Stein, J.C., 2007. Disagreement and the Stock Market. Journal of Economic Perspectives 21, 109-128.

[42] Iacoviello, M., 2005. House Prices, Borrowing Constraints, and Monetary Policy in the Business Cycle. American Economic Review 95, 739-64.

[43] Jaimovich, N., Rebelo, S., 2009. Can News about the Future Drive the Business Cycle? American Economic Review 99, 1097-1118.

[44] Jaimovich, N., Siu, H., 2009. The Young, the Old, and the Restless: Demographics and Business Cycle Volatility. American Economic Review 99, 804-826. 
[45] Jappelli, T., 1990. Who is Credit Constrained in the U.S. Economy? Quarterly Journal of Economics 105, 219-234.

[46] Kiyotaki, N., Moore, J., 1997. Credit Cycles. Journal of Political Economy 105, 211-248.

[47] Klein, P., 2000. Using the Generalized Schur Form to Solve a Multivariate Linear Rational Expectations Model. Journal of Economic Dynamics and Control 24, 1405-1423.

[48] Krishnamurthy, A., 2010. Amplification Mechanisms in Liquidity Crises. American Economic Journal: Macroeconomics 2, 1-33.

[49] Ljungqvist, L., Sargent, T.J., 2011. A Labor Supply Elasticity Accord? American Economic Review: Papers \& Proceedings 101, 487-491.

[50] Nakamura, E., Steinsson, J., 2008. Five Facts about Prices: A Reevaluation of Menu Cost Models. Quarterly Journal of Economics 123, 1415-1464.

[51] Piazzesi, M., Schneider, M., 2008. Inflation and the Price of Real Assets. Mimeo. University of Chicago and Stanford Univeristy.

[52] Rudebusch, G.D., 2002. Term Structure Evidence on Interest Rate Smoothing and Monetary Policy Inertia. Journal of Monetary Economics 49, 1161-1187.

[53] Schmitt-Grohé, S., Uribe, M., 2008. What's News in Business Cycles. National Bureau of Economic Research Working Paper 14215.

[54] Taylor, J.B., 2009. The Financial Crisis and the Policy Responses: An Empirical Analysis of What Went Wrong. National Bureau of Economic Research Working Paper 14631. 
Figure 1: Stylized features of housing-market boom-bust cycles in developed countries over 1970-2000

Real house price growth rate

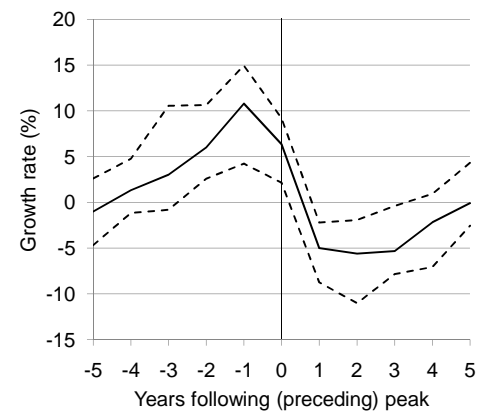

Actual hours worked growth rate

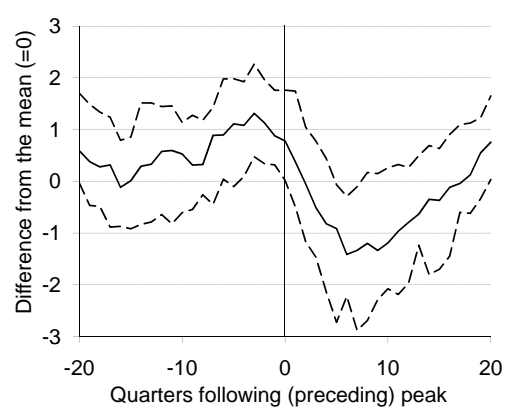

Short-term nominal interest rate

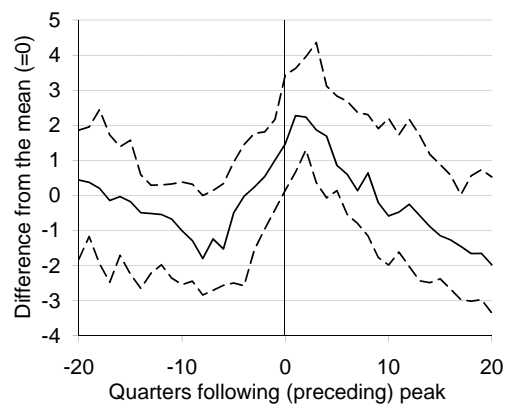

Real GDP growth rate

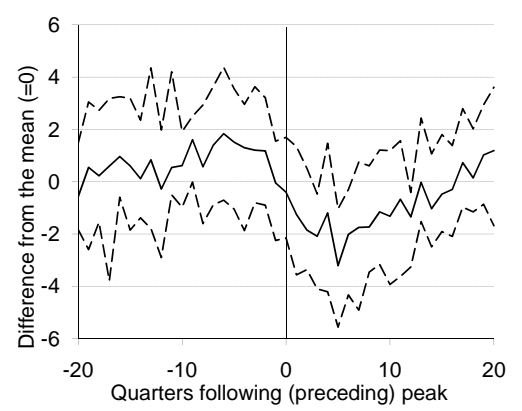

Employment growth rates for young and old workers

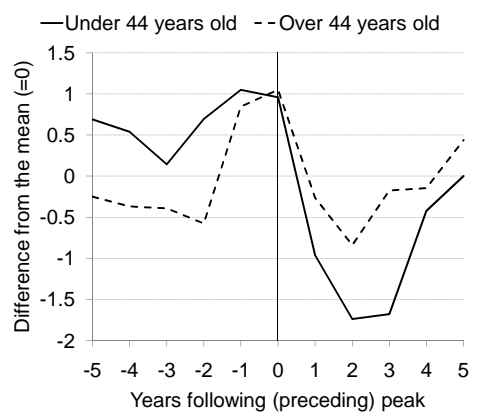

Total CPI inflation rate

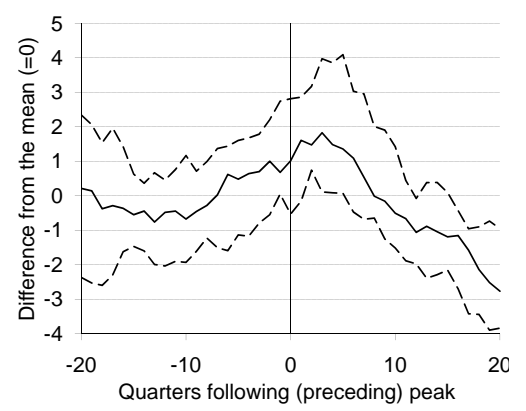

Real hourly earnings growth rate in manufacturing

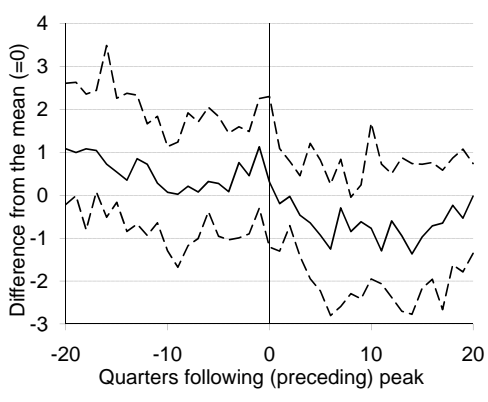

Short-term real interest rate

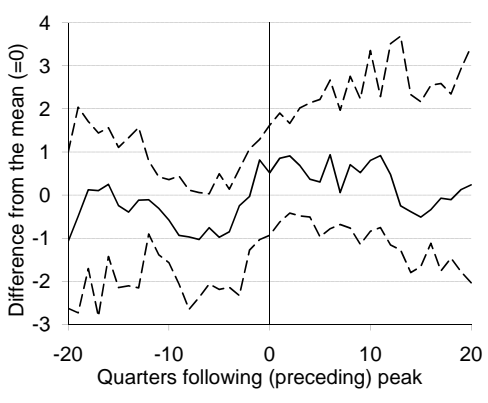

Notes: Except for employment growth rates for young and old workers, the solid line is the median of the variable in question in each quarter or year around the peaks of past housing booms in developed countries between 1970 and 2000, and the dashed lines below and above the solid line are the first and the third quartiles in each period, respectively. For employment growth rates for young and old workers, the solid line and the dashed line are the medians of annual employment growth rates for young and old workers, respectively. The real interest rates are ex-post rates. Period 0 corresponds to the peak quarters or years of housing booms in each panel. The unit of each vertical axis is a percentage point on an annualized basis. 
Figure 2: Real house price growth rates and differences in the Index of Consumer Expectations between young and old households in U.S. data

Index of Consumer Expectations
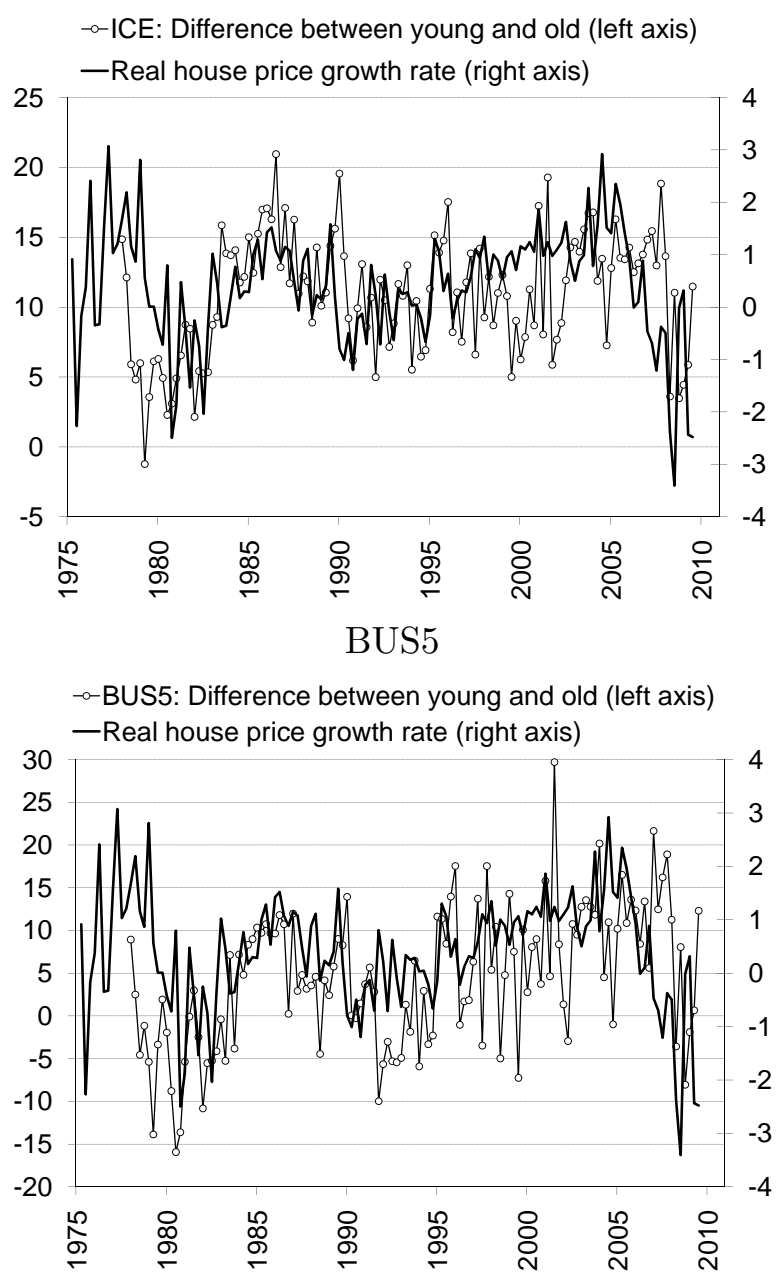

BUS12

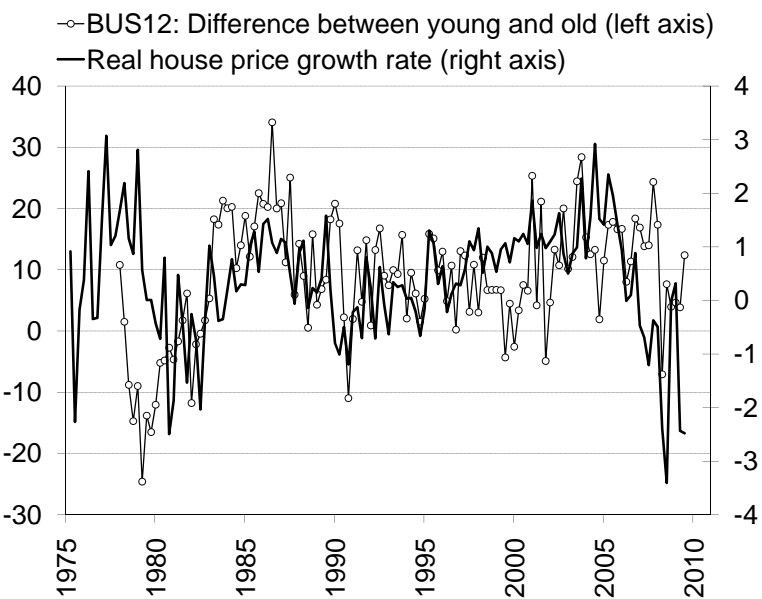

Notes: The real house price growth rates are the log differences on a quarterly basis. Positive values of "Difference between young and old" in each panel indicate that young households (under 44 years old) have stronger confidence in future economic conditions than old households (over 45 years old). "BUS12" represents household expectations of future financial conditions in the economy during the next 12 months and "BUS5" represents those of future employment conditions in the economy during the next 5 years. 
Figure 3: Housing-market boom-bust cycles with flexible prices
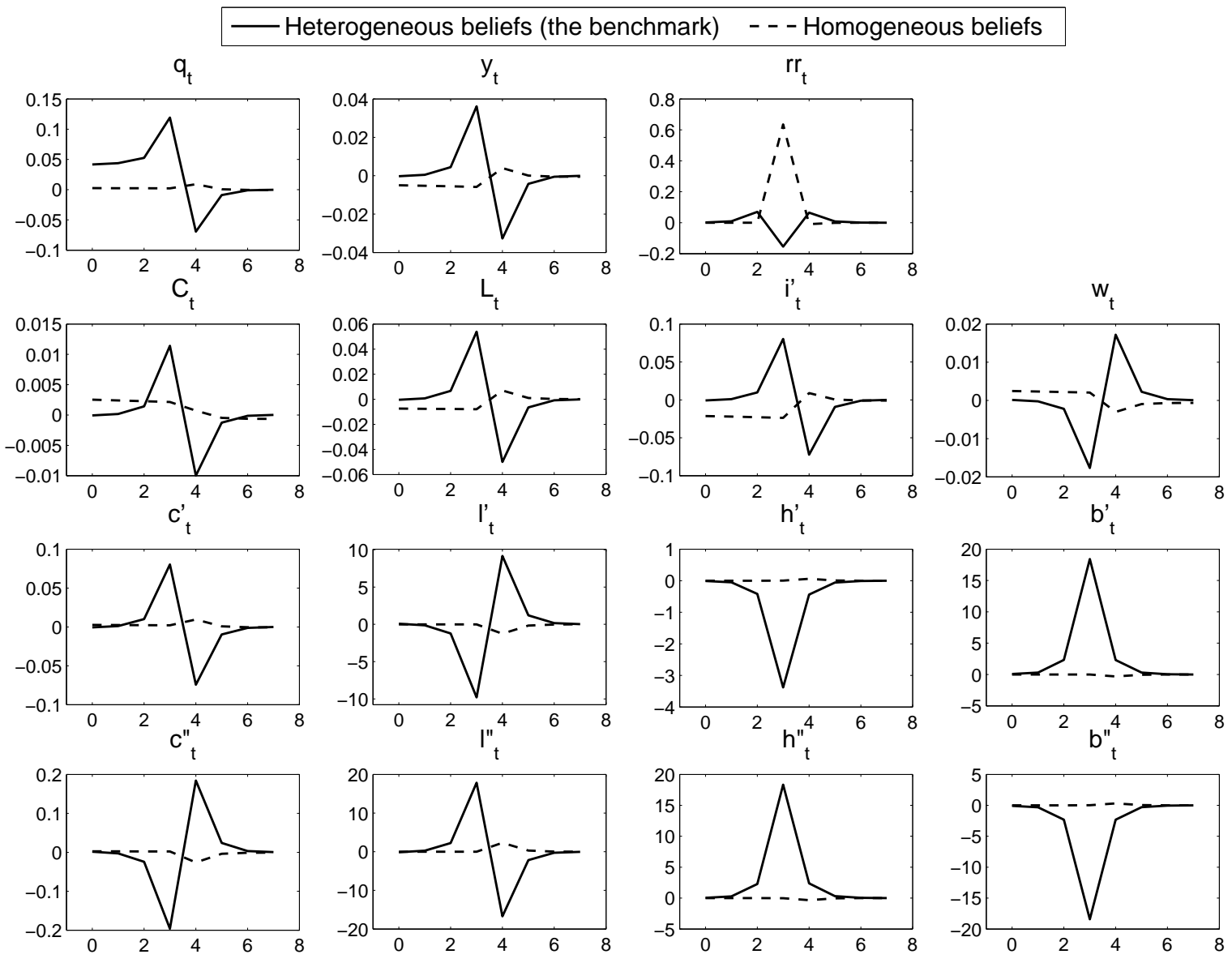

Notes: The solid line: mortgage borrowers consider the signal accurate, but savers regard the signal as a noise $\left(\nu_{A}^{\prime}=\infty\right.$ and $\left.\nu_{A}^{\prime \prime}=0\right)$. The dashed line: both mortgage borrowers and savers consider the signal accurate $\left(\nu_{A}^{\prime}=0\right.$ and $\left.\nu_{A}^{\prime \prime}=0\right)$. Figures are $\%$ deviations from the deterministic steady state. The signal is received in period 0 , but is not realized in period $4\left(z_{A, 0}=1\right.$ and $\left.\epsilon_{A, 4}=0\right)$. " $C_{t}$ " and " $L_{t}$ " denote aggregate consumption and labour supply, respectively. The economy is at the deterministic steady state before period 0 . The third and the forth rows show the actions of savers and mortgage borrowers, respectively. 
Figure 4: Impulse responses to a correct public signal
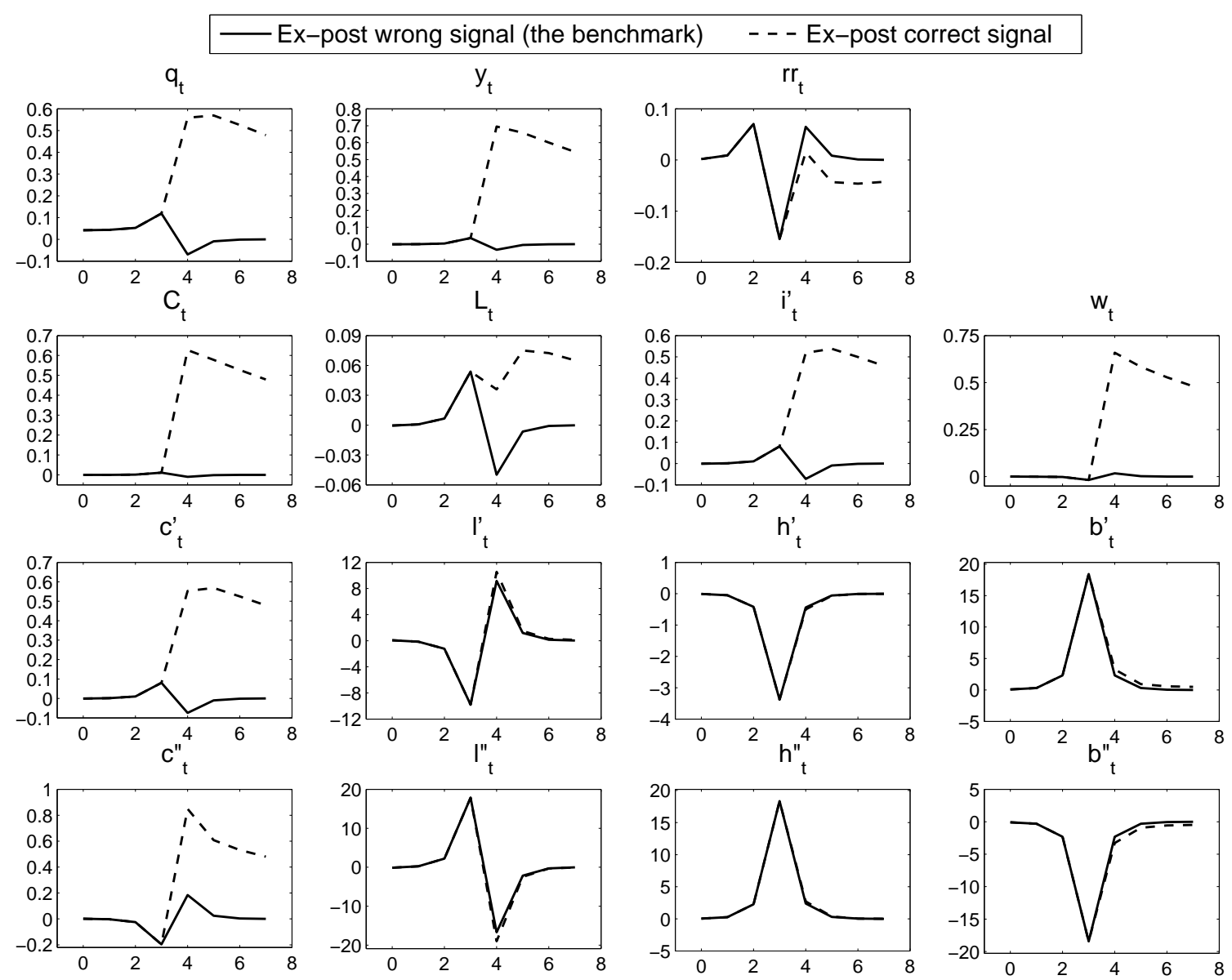

Notes: The solid line: the signal is received in period 0 , but is not realized in period $4\left(z_{A, 0}=1\right.$ and $\left.\epsilon_{A, 4}=0\right)$. The dashed line: the signal is received in period 0 and realized in period $4\left(z_{A, 0}=1\right.$ and $\left.\epsilon_{A, 4}=1\right)$. For all cases, mortgage borrowers consider the signal accurate, but savers regard the signal as a noise $\left(\nu_{A}^{\prime}=\infty\right.$ and $\left.\nu_{A}^{\prime \prime}=0\right)$. " $C_{t}$ " and " $L_{t}$ " denote aggregate consumption and labour supply, respectively. Figures are $\%$ deviations from the deterministic steady state. The economy is at the deterministic steady state before period 0 . The third and the forth rows show the actions of savers and mortgage borrowers, respectively. 
Figure 5: Effect of the availability of mortgage debt on housing-market boom-bust cycles
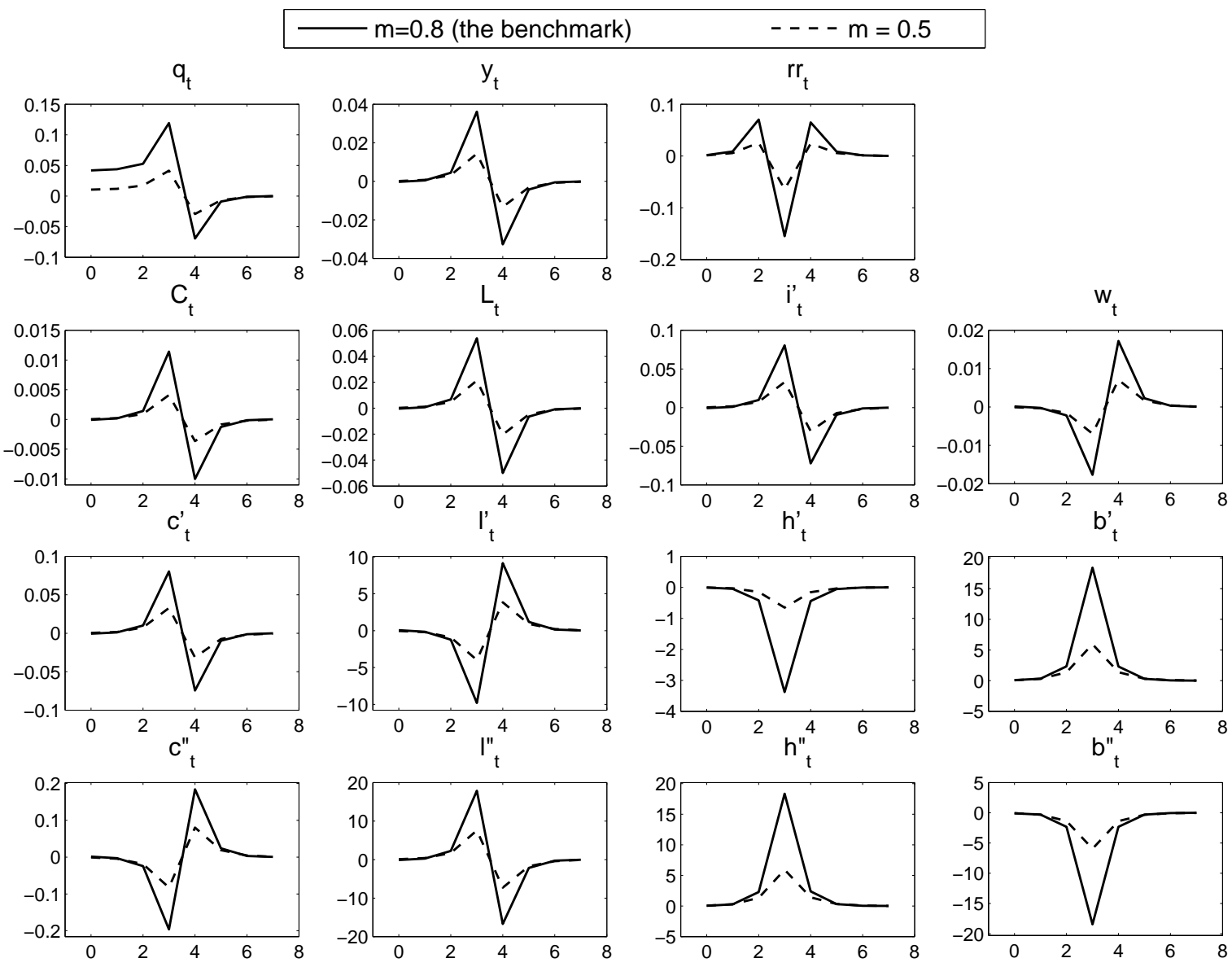

Notes: The parameter values other than $m$ are as shown in Table 3 for the flexible price case. Figures are $\%$ deviations from the deterministic steady state. The signal is received in period 0 , but is not realized in period $4\left(z_{A, 0}=1\right.$ and $\left.\epsilon_{A, 4}=0\right)$. Mortgage borrowers consider the signal accurate, but savers regard the signal as a noise $\left(\nu_{A}^{\prime}=\infty\right.$ and $\left.\nu_{A}^{\prime \prime}=0\right)$. " $C_{t}$ " and " $L_{t}$ " denote aggregate consumption and labour supply, respectively. The economy is at the deterministic steady state before period 0 . The third and the forth rows show the actions of savers and mortgage borrowers, respectively. 
Figure 6: Housing-market boom-bust cycles with sticky prices and heterogeneous labour supply elasticities
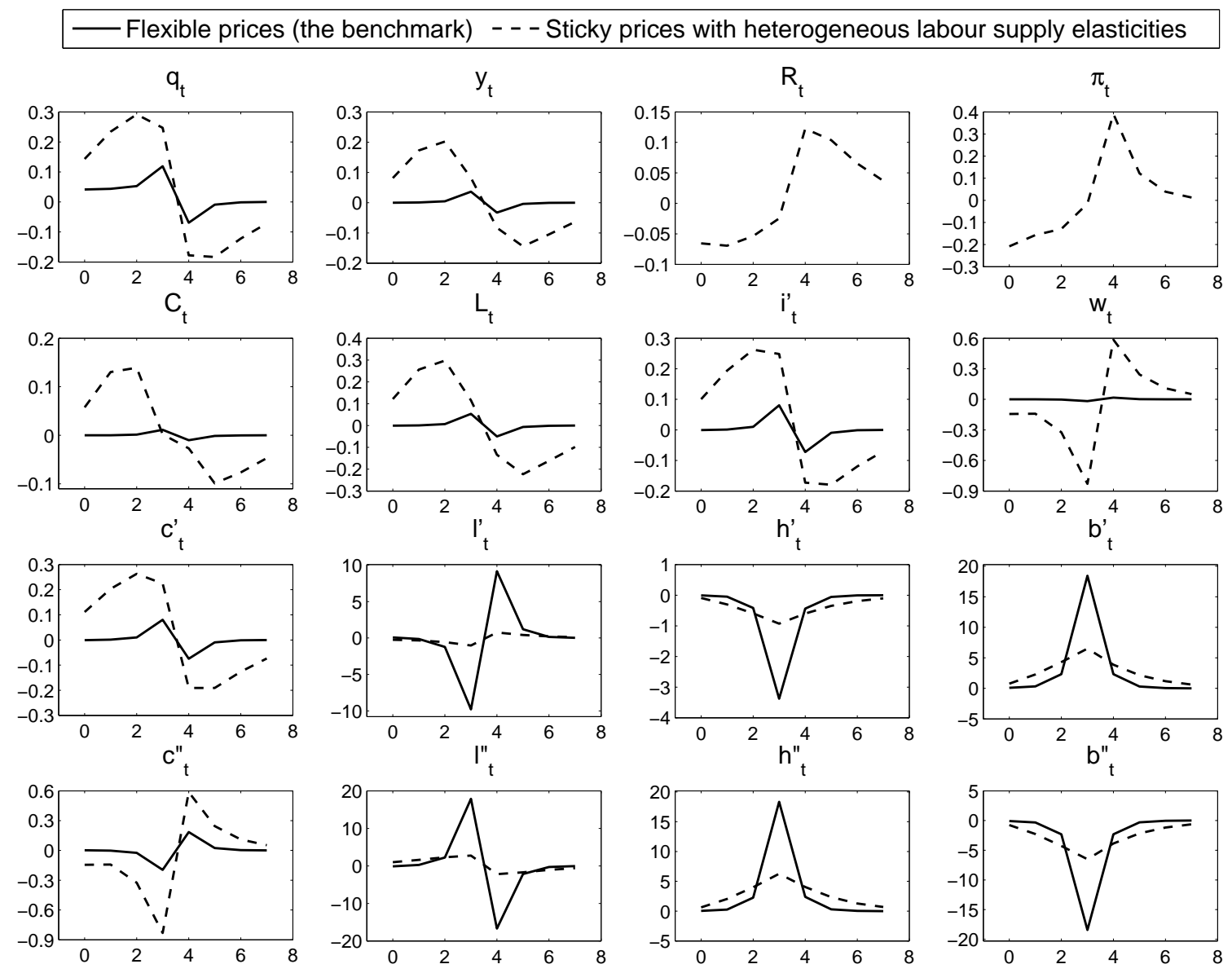

Notes: The solid line: flexible prices. The dashed line: sticky prices with heterogeneous labour supply elasticities. The parameter values for each case are as specified in Table 3. Figures are $\%$ deviations from the deterministic steady state. The signal is received in period 0 , but is not realized in period $4\left(z_{A, 0}=1\right.$ and $\epsilon_{A, 4}=0$ ). Mortgage borrowers consider the signal accurate, but savers regard the signal as a noise $\left(\nu_{A}^{\prime}=\infty\right.$ and $\left.\nu_{A}^{\prime \prime}=0\right)$. The economy is at the deterministic steady state before period 0 . The third and the forth rows show the actions of savers and mortgage borrowers, respectively. 
Table 1: The peak quarter of each housing boom in developed countries

\begin{tabular}{l|l}
\hline Australia & $1974: 1,1981: 2,1989: 2,1994: 3$ \\
Belgium & $1979: 3$ \\
Canada & $1976: 4,1981: 1,1989: 1$ \\
Denmark & $1973: 3,1979: 2,1986: 1$ \\
Finland & $1974: 1,1989: 2,2000: 2$ \\
France & $1981: 1,1991: 1$ \\
Germany & $1974: 1,1982: 1,1994: 2$ \\
Ireland & $1979: 2,1990: 3$ \\
Italy & $1974: 4,1981: 2,1992: 2$ \\
Japan & $1973: 4,1990: 4$ \\
Netherlands & $1978: 2$ \\
New Zealand & $1974: 3,1983: 1,1996: 2$ \\
Norway & $1976: 4,1987: 2$ \\
Spain & $1978: 2,1991: 4$ \\
Sweden & $1979: 3,1990: 1$ \\
Switzerland & $1973: 1,1989: 4$ \\
United Kingdom & $1973: 3,1980: 3,1989: 3$ \\
United States & $1973: 4,1979: 2,1989: 4$ \\
& \\
Source: Ahearne et al. $(2005)$.
\end{tabular}


Table 2: Regression of the U.S. real house price growth rate on heterogeneous household expectations

\begin{tabular}{lcccc}
\hline Regressors & 0-Lag & Coefficient estimates by OLS & \\
& & 1-Lag & 2-Lag & 3-Lag \\
\hline $\begin{array}{l}\text { ICE for young - ICE for old } \\
\left(\times 10^{-4}\right)\end{array}$ & $4.99^{* *}(1.88)$ & $-3.61(2.03)$ & $-1.18(1.96)$ & $-1.05(1.86)$ \\
& & & & \\
$\begin{array}{l}\text { ICE for all age cohorts } \\
\left(\times 10^{-4}\right)\end{array}$ & $2.14(1.10)$ & $-0.58(0.14)$ & $2.40(1.49)$ & $1.70(1.10)$ \\
Real GDP growth rate & $-0.21(0.10)$ & $-0.13(0.11)$ & $0.28^{* *}(0.09)$ & $-0.026(0.097)$ \\
Real 3-month T-bill rate & $-0.55^{* *}(0.20)$ & $0.68^{* *}(0.22)$ & $-0.43(0.24)$ & $0.098(0.22)$ \\
& & & & \\
$\begin{array}{l}\text { Lagged real house price } \\
\text { growth rate }\end{array}$ & & & & \\
& & & & \\
Constant & $-0.014^{* *}(0.004)$ & & & \\
\hline $\begin{array}{l}\text { Observations: } \\
\mathrm{R}^{2}:\end{array}$ & 123 & & & \\
\hline
\end{tabular}

Notes: The dynamic equation for the real house price growth rate $(y)$ is:

$$
y(t)=\alpha+\sum_{i=0}^{3} \beta_{i} x(t-i)+\sum_{i=1}^{3} \gamma_{i} y(t-i)+\sum_{i=0}^{3} \theta_{i}^{\prime} Z(t-i)+\epsilon_{t},
$$

where $x$ is the Index of Consumer Expectations (ICE) for young households (under 44 years old) minus the ICE for old households (over 45 years old), $Z=\{$ the average level of the ICE across all age cohorts, the real GDP growth rate, the ex-post real 3-month T-bill rate\}, and $\epsilon_{t}$ is an error term. The sample period is for 1978:1-2009:3. Standard errors are in the parentheses. ${ }^{* *}$ and ${ }^{*}$ mark $1 \%$ and $5 \%$ levels of significance, respectively. 
Table 3: Benchmark parameter values

\begin{tabular}{l|cc} 
& Flexible price case & Sticky price case \\
\hline Capital share of income $(\alpha)$ & 0.33 & \\
Depreciation rate $(\delta)$ & 0.025 & \\
Steady-state loan-to-value ratio $(m)$ & 0.8 & \\
Fraction of credit-constrained households $(1-\mu)$ & 0.25 & \\
Time discount factors $\left(\beta^{\prime}, \beta^{\prime \prime}\right)$ & $(0.99,0.95)$ & \\
Coefficient of investment function $\left(\eta_{K}\right)$ & $2 / \delta$ & \\
Weight on housing preference $(\gamma)$ & 0.1 & 1.03 for savers \\
Elasticity of substitution between inputs $(\theta)$ & 11 & 0.01 for borrowers \\
Persistence of productivity shocks $\left(\rho_{A}\right)$ & 0.01 & 0.5 \\
Inverse of labour supply elasticity $(\xi)$ & & $(1.53,0.93,0.73)$ \\
& 1 &
\end{tabular}

Note: The column for the sticky price case shows the parameter values only if they are different from those used for the flexible price case.

Table 4: Moments of aggregate variables in the calibrated model and the data

\begin{tabular}{|c|c|c|c|}
\hline & Variables & $\begin{array}{c}\text { Sticky price } \\
\text { model without } \\
\text { public signals }\end{array}$ & $\begin{array}{c}\text { Log-linearly } \\
\text { detrended } \\
\text { U.S. data }\end{array}$ \\
\hline \multirow{5}{*}{$\begin{array}{l}\text { Standard } \\
\text { deviations }\end{array}$} & Hours worked of savers (old workers) ${ }^{\dagger}$ & 0.793 & 0.794 \\
\hline & Hours worked of mortgage borrowers (young workers) ${ }^{\dagger}$ & 1.448 & 1.767 \\
\hline & Private investment & 1.492 & 5.206 \\
\hline & Private consumption & 0.913 & 0.764 \\
\hline & Aggregate hours worked & 0.401 & 1.711 \\
\hline
\end{tabular}

Notes: Standard deviations of the variables are divided by the standard deviation of final goods or GDP. ${ }^{\dagger}$ marks the moments targeted by the calibration of the values of $\xi$ for savers and mortgage borrowers using the sticky price version of the model without public signals. In the data, private investment is gross private domestic investment and private consumption is personal non-durable consumption expenditure. GDP, consumption, and investment are in real terms. Hours worked are actual hours worked. The hours worked data for young and old workers are used as proxies for the hours worked of mortgage borrowers and savers, respectively. 